\title{
Implementation of Ion Exchange Processes for Carbon Dioxide Mineralization Using Industrial Waste Streams
}

OPEN ACCESS

Edited by: Kaiqiang Zhang, Imperial College London, United Kingdom

Reviewed by:

Ziqing Pan,

Imperial College London, United Kingdom

Adam Hughmanick Berger, Electric Power Research Institute (EPRI), United States

*Correspondence:

Dante A. Simonetti dasimonetti@ucla.edu

Present address: Abdulaziz Alturki, Department of Chemical Engineering, King Abdulaziz University, Rabigh, Saudi Arabia

${ }^{\ddagger}$ Present address: Erika Callagon La Plante, Department of Materials Science and Engineering, University of Texas, Arlington, TX, United States

Specialty section: This article was submitted to Advanced Clean Fuel Technologies,

a section of the journal

Frontiers in Energy Research

Received: 25 September 2020 Accepted: 18 November 2020 Published: 10 December 2020

Citation:

Bustillos S, Alturki A, Prentice D, La

Plante EC, Rogers $M$, Keller $M$,

Ragipani $R$, Wang $B$, Sant $G$ and Simonetti DA (2020) Implementation of Ion Exchange Processes for Carbon

Dioxide Mineralization Using Industrial Waste Streams.

Front. Energy Res. 8:610392. doi: 10.3389/fenrg.2020.610392

\author{
Steven Bustillos ${ }^{1,2}$, Abdulaziz Alturki ${ }^{1 \dagger}$, Dale Prentice ${ }^{2,3,4}$, Erika Callagon La Plante ${ }^{2,3 \neq}$, \\ Mitchell Rogers ${ }^{1}$, Mark Keller ${ }^{1}$, Raghavendra Ragipani ${ }^{5}$, Bu Wang ${ }^{5}$, Gaurav Sant ${ }^{2,3,4,6,7}$ and \\ Dante A. Simonetti ${ }^{1,3 *}$
}

\begin{abstract}
${ }^{1}$ Department of Chemical and Biomolecular Engineering, University of California Los Angeles, Los Angeles, CA, United States, ${ }^{2}$ Department of Civil and Environmental Engineering, Laboratory for the Chemistry of Construction Materials (LC2), University of California Los Angeles, Los Angeles, CA, United States, ${ }^{3}$ Institute for Carbon Management, University of California, Los Angeles, Los Angeles, CA, United States, ${ }^{4}$ Department of Civil and Environmental Engineering, University of California, Los Angeles, Los Angeles, CA, United States, ${ }^{5}$ Department of Civil and Environmental Engineering, University of Wisconsin, Madison, WI, United States, ${ }^{6}$ Department of Materials Science and Engineering, University of Califomia, Los Angeles, Los Angeles, CA, United States, ${ }^{7}$ California NanoSystems Institute, University of California, Los Angeles, Los Angeles, CA, United States
\end{abstract}

Sequestration of $\mathrm{CO}_{2}$ within stable mineral carbonates (e.g., $\mathrm{CaCO}_{3}$ ) represents an attractive emission reduction strategy because it offers a leakage-free alternative to geological storage of $\mathrm{CO}_{2}$ in an environmentally benign form. However, the $\mathrm{pH}$ of aqueous streams equilibrated with gaseous streams containing $\mathrm{CO}_{2}(\mathrm{pH}<4)$ are typically lower than that which is required for carbonate precipitation $(\mathrm{pH}>8)$. Traditionally, alkalinity is provided by a stoichiometric reagent (e.g., $\mathrm{NaOH}$ ) which renders these processes environmentally hazardous and economically unfeasible. This work investigates the use of regenerable ion-exchange materials to induce alkalinity in $\mathrm{CO}_{2}$-saturated aqueous solutions such that the $\mathrm{pH}$ shift required for mineralization occurs without the need for stoichiometric reagents. $\mathrm{Na}^{+}-\mathrm{H}^{+}$exchange isotherms $\left(\right.$at $\left[\mathrm{H}^{+}\right]=$ $10^{-8}-10^{-1} \mathrm{M}$ ) and rates were measured for 13X and 4A zeolites and TP-207 and TP-260 organic exchange resins in batch equilibrium and fixed-bed exchange experiments, respectively. At solutions equilibrated with $\mathrm{CO}_{2}$ at $1.0 \mathrm{~atm}(\mathrm{pH}=3.9), \mathrm{H}^{+}$exchange capacities for the materials were similar (1.7-2.4 mmol $\mathrm{H}^{+} / \mathrm{g}$ material) and resulted in $\mathrm{pH}$ increases from 3.9 to greater than 8.0. Multi-component mixtures using $\mathrm{Ca}^{2+}$ and $\mathrm{Mg}^{2+}$ cations (at $10^{-3}-10^{-1} \mathrm{M}$ ) in $\mathrm{CO}_{2}$-saturated water were used to probe competitive ion exchange. The presence of divalent cations in solution inhibited $\mathrm{H}^{+}$exchange, reducing capacities to as low as $0.2 \mathrm{mmol} \mathrm{H}^{+} / \mathrm{g}$ for both resins and zeolites. Dynamic $\mathrm{H}^{+}$exchange capacities in fixed-bed ion exchange columns were similar to equilibrium values for resins $(\sim 1.5 \mathrm{mmol} / \mathrm{g})$ and zeolites $(\sim 0.8 \mathrm{mmol} / \mathrm{g})$ using inlet solutions that were equilibrated with gaseous streams of $\mathrm{CO}_{2}$ at $1.0 \mathrm{~atm}$. However, exchange kinetics were limited by intraparticle diffusion as indicated by the increased rate parameters with increasing inlet flow rates $\left(20-160 \mathrm{~cm}^{3} \mathrm{~min}^{-1}\right)$. Experimental calcite precipitation from mixing the alkaline $\mathrm{CO}_{3}{ }^{2-}$-rich water solution obtained from the ion-exchange column with a simulated liquid waste stream solution achieved thermodynamic maximum yields. The 
results from these studies indicate that ion exchange processes can be used as an alternative to the addition of stoichiometric bases to induce alkalinity for the precipitation of $\mathrm{CaCO}_{3}$, thereby opening a pathway toward sustainable and economic mineralization processes.

Keywords: carbon dioxde, mineralization, sustainable manufacturing, calcium carbonate, ion exchange

\section{INTRODUCTION}

From 1975 to 2018 , atmospheric $\mathrm{CO}_{2}$ levels have dramatically increased from 250 to $410 \mathrm{ppm}$. The International Energy Outlook reported that world energy carbon dioxide $\left(\mathrm{CO}_{2}\right)$ emissions would reach 35 gigatons $\mathrm{CO}_{2}$ equivalent $\left(\mathrm{Gt} \mathrm{CO}_{2} \mathrm{e}\right)$ by 2020 (IEA, 2020b). Of these emissions, thirty-two percent $\left(17.8 \mathrm{Gt} \mathrm{CO}_{2}{ }^{\mathrm{e}}\right.$ ) have been generated during primary energy consumption of oil and gas in the transportation and industrial sectors (IEA, 2019; IEA, 2020a). In the United States, transportation emissions (totaling $1.9 \mathrm{Gt} \mathrm{CO}_{2} \mathrm{e}$ in 2018 Nyquist and Ruys, 2009; IEA, 2019) are generated via distributed sources and must be mitigated via direct air capture technology, industrial power generation $\left[1.0 \mathrm{Gt} \mathrm{CO}_{2} \mathrm{e}\right.$ in 2018 from direct combustion of fossil fuels for energy (Nyquist and Ruys, 2009; IEA, 2019)] can be considered as point sources of $\mathrm{CO}_{2}$. In addition to non-electric power generation, oil and gas production operations (i.e., refineries, onshore oil and natural gas production, and natural gas processing) contribute greater than $10 \%$ [0.34 Gt $\mathrm{CO}_{2}$ e per year (Sofia Plagakis, 2013; Allen, 2016; U.S. Department of Energy, 2019)] of emissions associated with the oil and gas sector.

Post-combustion capture of $\mathrm{CO}_{2}$ [e.g., from power plants using amine-based processes (Kim et al., 2016; El Hadri et al., 2017; Kar et al., 2019)] and storage in geological formations (CCS) is the current state-of-the-art for $\mathrm{CO}_{2}$ emissions mitigation. Decades of process optimization (Cohen et al., 2012; Mores et al., 2014; Bui et al., 2014) and large theoretical storage capacities in the United States (Drage et al., 2012; Armstrong and Styring, 2015; Zhang et al., 2016) make amine-based CCS processes particularly effective for large point source emitters [e.g., fossil fuel fired power plants (Manzolini et al., 2015; Dutcher et al., 2015; Rao and Rubin, 2020)]. However, large energy demands [>0.36 MWh per ton $\mathrm{CO}_{2}$ captured for streams with less than $12 \% \mathrm{CO}_{2}$ (Dutcher et al., 2015; Liu et al., 2019)], high capital costs of large amine plants (Dutcher et al., 2015; Oh et al., 2018; Baseline Survey, 2019), and high operating expenses (e.g., for pipeline transportation and for storage site monitoring) are barriers for the use of amine-based processes in the oil and gas sector where emissions are more dilute and/or distributed [e.g., less than 3\% $\mathrm{CO}_{2}$ in flare gases from refineries, petrochemical plants, and natural gas wells (Chaikittisilp et al., 2011; Choi et al., 2011a; Choi et al., 2011b)]. Thus, the low carbon future envisioned to combat climate change will require new technologies for $\mathrm{CO}_{2}$ emissions mitigation from primary energy users and during oil and gas recovery.

Sequestration of $\mathrm{CO}_{2}$ as a solid carbonate (i.e., mineralization) is an alternative emission mitigation strategy opposed to post- combustion capture of $\mathrm{CO}_{2}$. $\mathrm{CO}_{2}$ is captured as a stable carbonate solid (usually in the form of calcium or magnesium carbonates) via chemical reaction with $\mathrm{Ca} / \mathrm{Mg}$ ions in alkaline aqueous solutions (Seifritz, 1990; Azdarpour et al., 2014). Mineralization-based $\mathrm{CO}_{2}$ capture and storage involve inherently lower energy processes because the $\mathrm{CO}_{2}$ capture and storage occur without requiring a separate removal/ concentration step (i.e., absorption from a vapor phase). These processes also exploit the favorable thermodynamics of carbonate precipitation reactions $(\Delta \mathrm{G}=-1129.1 \mathrm{~kJ} / \mathrm{mol}$ for calcite precipitation). By avoiding the $\mathrm{CO}_{2}$ capture steps, mineralization-based approaches can be applied across a wide range of $\mathrm{CO}_{2}$ concentrations (i.e., atmospheric concentrations to 100 vol. $\% \mathrm{CO}_{2}$ ) and temperatures (i.e., ambient to $\sim 90{ }^{\circ} \mathrm{C}$ ) without increasing energy requirements [i.e., associated with large heat duties for thermal swing amine-based processes (Zhang et al., 2016)]. These processes are also insensitive to the impurities in $\mathrm{CO}_{2}$-containing streams (e.g., hydrocarbons and $\mathrm{H}_{2} \mathrm{~S}$ ). Thus, mineralization approaches represent an attractive alternative to CCS for $\mathrm{CO}_{2}$ emission mitigation in the oil and gas sector because reduced process complexity and broad operating conditions enable modularity with few unit operations (i.e., process intensification) and flexibility in fulfilling carbon management goals across diverse locations and settings without the need for transport infrastructure (e.g., pipelines, compression stations, etc.).

$\mathrm{CO}_{2}$ mineralization (e.g., as calcium carbonate) occurs via the following reaction

$$
\mathrm{Ca}^{2+}(\mathrm{aq})+\mathrm{CO}_{3}^{2-}(\mathrm{aq}) \rightarrow \mathrm{CaCO}_{3}(\mathrm{~s})
$$

The speciation reactions that describe the $\mathrm{CO}_{2}-\mathrm{H}_{2} \mathrm{O}$ system are written as:

$$
\begin{gathered}
\mathrm{CO}_{2}(\mathrm{~g})+\mathrm{H}_{2} \mathrm{O} \rightleftharpoons \mathrm{CO}_{2}(\mathrm{aq})+\mathrm{H}_{2} \mathrm{O} \rightleftharpoons \mathrm{H}_{2} \mathrm{CO}_{3}(\mathrm{aq}) \\
\mathrm{H}_{2} \mathrm{CO}_{3}(\mathrm{aq}) \rightleftharpoons \mathrm{H}^{+}(\mathrm{aq})+\mathrm{HCO}_{3}^{-}(\mathrm{aq}) \\
\mathrm{HCO}_{3}^{-}(\mathrm{aq}) \rightleftharpoons \mathrm{H}^{+}(\mathrm{aq})+\mathrm{CO}_{3}^{2-}(\mathrm{aq})
\end{gathered}
$$

In general, the concentration of $\mathrm{CO}_{3}{ }^{2-}$ anions (and thus, the extent of carbonate precipitation) depends on $\mathrm{pH}$ (e.g., in water, $\mathrm{CO}_{3}{ }^{2-}$ is the dominant carbon species at $\mathrm{pH}>10.33$ (King and Farlow, 2000; Cerozi and Fitzsimmons, 2016), so the mineralization strategy described above requires sources of $\mathrm{Ca} /$ $\mathrm{Mg}$ ions and alkalinity. Approximately 22 billion barrels of liquidwaste water, known as produced water $(\mathrm{PW})$, is produced during oil and gas extraction yearly (Guerra et al., 2011; Roach et al., 2013; Dastgheib et al., 2014; Scanlon et al., 2020;). The vast majority of PW is injected for disposal, resulting in only $0.6 \%$ of PW utilized for beneficial reuse (Guerra et al., 2011; Dastgheib et al., 2014; Scanlon et al., 2020). After separation of organic 
components, $\mathrm{PW}$ is rich in primarily $\mathrm{Na}^{+}, \mathrm{Ca}^{2+}, \mathrm{Mg}^{2+}$ and $\mathrm{Cl}^{-}$ ions (0.050-3.0 M) (Blondes et al., 2018). These high cation concentrations make PW viable sources of cations for mineralization processes. However, these streams are typically produced at $4<\mathrm{pH}<7$ (with bicarbonate, $\mathrm{HCO}_{3}{ }^{-}$, as the predominant species) (Blondes et al., 2018). The addition of caustic soda $(\mathrm{NaOH})$ to increase the $\mathrm{pH}$ of these streams would render mineralization processes uneconomical because of the costs and hazards of using $\mathrm{NaOH}$. Previous studies have explored the use of alkaline solid wastes (i.e., combustion fly ashes and slags) (Teir et al., 2007; Said et al., 2013; Chang et al., 2017; Humbert and Castro-Gomes, 2019), however, this still involves the use of a stoichiometric reagent whose production occurs in much lower abundance (130 million tons per year) (Federal Highway Administration, 2016; Humbert and CastroGomes, 2019) compared to $\mathrm{CO}_{2}$ emissions from oil and gas processes (2.9 billion tons per year).

In this work, we investigate the use of ion exchange (IEX) processes as an alternative method to induce alkalinity for the precipitation of $\mathrm{CaCO}_{3}$ using wastewater streams. Exposing $\mathrm{CO}_{2}$ saturated solutions $(\mathrm{pH}=3.9)$ to regenerable IEX materials can shift the $\mathrm{pH}$ to $>10.0$, thereby creating favorable conditions for $\mathrm{CO}_{2}$-mineralization reactions. Ion exchange occurs between an electrolyte solution and similarly charged ions immobilized in an IEX material through a stoichiometric, reversible IEX reaction. Previous research has shown the reversible exchange of $\mathrm{H}^{+}$and $\mathrm{Na}^{+}$ions in a solution using clay minerals (Avena and De Pauli, 1998; Klein et al., 2010; Robin et al., 2015). $\mathrm{H}^{+}-\mathrm{Na}^{+}$ion exchange is described by:

$$
\mathrm{H}^{+}+\mathrm{R}^{\mathrm{Na}} \leftrightarrow \mathrm{R}^{\mathrm{H}}+\mathrm{Na}^{+}
$$

where $\mathrm{R}^{\mathrm{Na} / \mathrm{H}}$ is the IEX material in either sodium or proton form and $\mathrm{H}^{+}$and $\mathrm{Na}^{+}$are ions in solution. Protons in solution are introduced by dissolving $\mathrm{CO}_{2}\left(\mathrm{pCO}_{2}=1.0 \mathrm{~atm}\right.$; $\mathrm{pH}$ 3.9) into water according to Eqs. 2-4. As protons are removed from the solution via ion exchange, the equilibria of reactions $2-4$ shifts toward the formation of $\mathrm{CO}_{3}{ }^{2-}$ ions. (Druckenmiller and Maroto-Valer, 2005) The resulting solution after IEX is an alkaline, $\mathrm{CO}_{3}{ }^{2-}$-rich solution that can be used for $\mathrm{CaCO}_{3}$ precipitation without the addition of caustic soda. The regeneration energy requirement for $\mathrm{CO}_{2}$ capture using solid IEX materials is significantly lower than that of dry solid adsorbent and aqueous amine-based processes due to the absence of heat requirement since the process uses a concentrated sodium chloride waste stream to regenerate the materials (as described in this work) (Rao and Rubin, 2020).

IEX technology is commonly used to purify solutions by removing the dissolved ions by electrostatic sorption into IEX materials of various physical forms (Harland, 1994; Nasef, 2008). All zeolites can serve as IEX materials because of their specific structural features. However, for practical applications, highalumina zeolites, or zeolites with $\mathrm{Si} / \mathrm{Al}$ ratios in the range of 1-5 (Flanigen et al., 2010), are preferred for IEX applications because of the large number of acid sites (Inglezakis, 2005). IEX and selectivity in zeolites are mainly affected by the properties of the exchangeable cations, the concentration of the solution, the presence of other cations and the characteristics of the zeolite such as channels and $\mathrm{Si} / \mathrm{Al}$ ratios (Kirov and Filizova, 2012). Type $\mathrm{A}$ and Type $\mathrm{X}$ zeolites have high affinities for proton exchange in solutions of $\mathrm{pH} 3.9-7$ because of their small $\mathrm{Si} / \mathrm{Al}$ ratios (Munthali et al., 2014), making them suitable materials for a $\mathrm{pH}$ swing process. IEX resins contain functionalized ionizable groups placed along their polymer-backbone chains and are classified depending on the functional group into weakly (WAC) and strongly (SAC) acidic materials. The high $\mathrm{H}^{+}$ affinity of WAC resins makes it advantageous to use instead of SAC resins because they can be regenerated using weakly acidic feeds. The pKa of the functional groups on WAC resins are generally greater than 2 , whereas $\mathrm{SAC}$ resins generally require concentrated acids $(\mathrm{pH}<2)$ because of the functional group's smaller pKa values (Kunin and Vassiliou, 1963; Leaković et al., 2000; Guo et al., 2013; Maul et al., 2014; Víctor-Ortega et al., 2017).

This work aims to identify commercially available IEX materials capable of shifting the $\mathrm{pH}$ of $\mathrm{CO}_{2}$-saturated solutions for subsequent precipitation as carbonates. Commercially available WAC resins (TP-207, TP-260) and synthetic zeolites (Type 4A, Type 13X) were selected to quantify exchange capacities and kinetic exchange parameters. These resins and synthetic zeolites were selected because of their weakly acidic functional groups and small $\mathrm{Si} / \mathrm{Al}$ ratios (1.0 for Type 4A and 1.24 for Type 13X), respectively. IEX was studied across a range of $\mathrm{H}^{+}$concentrations from $\mathrm{HCl}$ and $\mathrm{CO}_{2}$ batch solutions to determine the effect of proton and anion concentrations on the exchange capacities of these materials. Equilibrium IEX isotherms were developed for materials and compared with competitive ions to determine the process design and configuration. IEX kinetic constants and capacities are quantified using simple linear driving force (LDF) models for dynamic IEX experiments performed by column exchange. Materials were regenerated to quantify working capacities and kinetics. Furthermore, $\mathrm{CO}_{2}$ mineralization was performed using simulated PW streams as the source for calcium ions (Otton and Kharaka, 2003; Roach et al., 2013; Dastgheib et al., 2014; Blondes et al., 2018) and the effluent solution compositions from the IEX columns. Geochemical modeling to rapidly estimate the propensity of formation of minerals in solution (e.g., $\mathrm{CaCO}_{3}$ ) was performed using Gibbs Energy Minimization (GEM) software (Kulik et al., 2012; Wagner et al., 2012). The work presented herein demonstrates these processes by identifying suitable materials and process parameters and by presenting possible strategies for integration with various processes related to the oil and gas sector.

\section{MATERIALS AND METHODS}

\section{Materials}

Sodium chloride $(\mathrm{NaCl},>99.0 \%)$, calcium chloride dihydrate $\left(\mathrm{CaCl}_{2} \cdot 2 \mathrm{H}_{2} \mathrm{O},>99.0 \%\right)$, calcium sulfate dihydrate $\left(\mathrm{CaSO}_{4} \cdot 2 \mathrm{H}_{2} \mathrm{O}\right.$, $>99.0 \%$ ), ferric chloride hexahydrate $\left(\mathrm{FeCl}_{3} \cdot 6 \mathrm{H}_{2} \mathrm{O},>99.0 \%\right)$, potassium chloride $(\mathrm{KCl},>99.0 \%)$ and magnesium chloride hexahydrate $\left(\mathrm{MgCl}_{2} \cdot 6 \mathrm{H}_{2} \mathrm{O}\right.$, >99.0\%) were all purchased from Fisher Chemicals. $70 \%(\mathrm{w} / \mathrm{w})$ nitric acid $\left(\mathrm{HNO}_{3}\right)$ and $12.5 \%(\mathrm{w} / \mathrm{w})$ 
hydrochloric acid $(\mathrm{HCl})$ solutions were purchased from Sigma Aldrich. High purity carbon dioxide $\left(\mathrm{CO}_{2}, 99.99 \%\right.$, Airgas) cylinders were used as the source for the preparation of $\mathrm{CO}_{2^{-}}$ saturated solutions. All chemicals were used as received unless otherwise stated. Commercially available synthetic zeolites (4A and 13X; 8-12 mesh; Fisher Chemicals) and sodium-form chelating cation exchange resins (Lewatit TP 207 (iminodiacetate functional groups) and Lewatit TP 260 (aminomethyl phosphonate functional groups); Sigma Aldrich) were used for IEX experiments. Cation exchange resins were preconditioned using $2 \mathrm{~N} \mathrm{HCl}$ (Sigma Aldrich), $1 \mathrm{~N}$ $\mathrm{NaOH}$ (Sigma Aldrich), and washed with ultra-pure water (MilliQ, resistance of $18.2{\mathrm{M} \Omega \mathrm{cm}^{-1}}^{-1}$ to remove any contaminants and ensure resins are $\mathrm{Na}^{+}$-form at saturation (Seggiani et al., 2006).

Chemical analysis of ion-exchange materials (Supplementary Table S1) was performed by electron dispersion spectroscopy (EDS; Nova 230 model) with a $10 \mathrm{kV}$ accelerating voltage and a working distance of $5 \mathrm{~mm}$. Brunauer-Emmett-Teller (BET) surface areas were calculated from $\mathrm{N}_{2}$ adsorption-desorption isotherms, measured at $77 \mathrm{~K}$ with a Micrometrics ASAP 2020 Plus I system. Before measurements, samples were degassed at $1 \times$ $10^{-3}$ Torr, and $573 \mathrm{~K}$. Pore size distributions were calculated from the adsorption branches of the isotherms using the BarrettJoyner-Halenda (BJH) model. Bulk porosities and densities were measured using helium pycnometry (AccuPyc II 1340, Micrometrics) after drying the materials at $65^{\circ} \mathrm{C}$ for $3 \mathrm{~h}$. Additionally, particle size distributions were measured using static light scattering (SLS; LS13-320, Beckman Coulter Static Light Scattering) with water and sonication being used to ensure particle dispersion. A summary of material properties is shown in Supplementary Table S2.

\section{Batch Equilibrium Ion-Exchange Experiments}

Single component IEX experiments using $\mathrm{HCl}$ and $\mathrm{CO}_{2}$-saturated solutions $\left(\mathrm{pCO}_{2}=1.0 \mathrm{~atm}, \mathrm{pH}=3.9\right)$ were performed to determine $\mathrm{Na}^{+}-\mathrm{H}^{+}$exchange isotherms. Aqueous solutions with $0.001,0.010,0.1,0.25$, and $0.5 \mathrm{M}$ of $\mathrm{HCl}$ were prepared by diluting $12.5 \% \quad(\mathrm{w} / \mathrm{w}) \mathrm{HCl}$ with ultra-pure water $\left(18.2 \mathrm{M} \Omega \mathrm{cm}^{-1}\right) . \quad \mathrm{CO}_{2}$-saturated solutions were prepared by bubbling $\mathrm{CO}_{2}$ into ultra-pure water at $25^{\circ} \mathrm{C}$, where $[\mathrm{CO} 2]=$

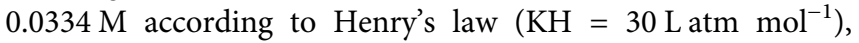
resulting in a saturation $\mathrm{pH}$ of 3.9 (Bhaduri et al.). $\mathrm{CO}_{2}$ was bubbled until a stable $\mathrm{pH}$ of 3.9 was read using a $\mathrm{pH}$ electrode (Thermo Scientific Orion Versa Star). Exchange capacities for divalent cations were measured using 0.001, 0.010, 0.1, 0.25, 0.5, and $1 \mathrm{M}$ of $\mathrm{CaCl}_{2}$ and $\mathrm{MgCl}_{2}$ separately, prepared in ultra-pure water. All experiments were performed using a solid/liquid ratio of $0.003 \mathrm{~g} / \mathrm{ml}$ and at $25^{\circ} \mathrm{C}$ unless otherwise stated. All batch equilibrium experiments were performed using tightly sealed conical centrifuge tubes of equal dimensions and shaken continuously using a Corning LSE orbital shaker for four days. Solutions from all batch equilibrium experiments were sampled at $5,10,30,60,100,180$, and $240 \mathrm{~min}$, and every $24 \mathrm{~h}$ afterward for cation concentration analysis by inductively coupled plasma-optical emission spectroscopy (ICP-OES; Avio 200 ICP Optical Emission Spectrometer, Perkin Elmer) to ensure equilibrium was achieved. Samples were filtered through a $0.2-$ micron Corning filter and diluted in $5 \%(\mathrm{w} / \mathrm{w}) \mathrm{HNO}_{3}$ (prepared by diluting $70 \% \mathrm{HNO}_{3}$ in ultra-pure water).

Equilibrium was established when cation concentrations in solution were invariant with time. Equilibrium exchange capacities (EC; mmol/g) were calculated by

$$
\mathrm{EC}=\frac{\left(C_{0}-C_{f}\right) \cdot V}{W}
$$

where $C_{f}$ and $C_{o}$ are final and initial cation concentrations in solution, respectively, $V$ is the solution volume, and $W$ is the mass of solid.

Competitive IEX was performed using the following solutions (summarized in Supplementary Tables S3-S6) containing Na$\mathrm{Ca}, \mathrm{Na}-\mathrm{Mg}, \mathrm{Mg}-\mathrm{Ca}, \mathrm{HCl}-\mathrm{NaCl}$ and $\mathrm{CO}_{2}-\mathrm{NaCl}$ (saturated $\mathrm{CO}_{2}$ in solution at $\mathrm{pCO}_{2}=1.0 \mathrm{~atm}$ ). Binary $\mathrm{Na}-\mathrm{Ca}$ and $\mathrm{Na}-\mathrm{Mg}$ solutions contained a fixed concentration of $1 \mathrm{M} \mathrm{NaCl}$ with $\mathrm{CaCl}_{2}$ and $\mathrm{MgCl}_{2}$ concentrations varying from 0.001 to $1 \mathrm{M}$. Binary Ca-Mg solutions contained equimolar concentrations of each cation varying from 0.001 to $1 \mathrm{M}$. Binary $\mathrm{HCl}-\mathrm{NaCl}$ experiments consisted of a fixed concentration of $1 \mathrm{M} \mathrm{HCl}(\mathrm{pH}=0.2)$ for resin experiments and $0.1 \mathrm{M} \mathrm{HCl}(\mathrm{pH}=1.0)$ for zeolite experiments with varying $\mathrm{NaCl}$ concentrations from 0.001 to $1 \mathrm{M}$. Ternary IEX experiments (summarized in Supplementary Table S7) were performed in solutions composed of $\mathrm{CO}_{2}-\mathrm{NaCl}-$ $\mathrm{CaCl}_{2}$ to further quantify competitive exchange between $\mathrm{H}^{+}, \mathrm{Na}^{+}$, and $\mathrm{Ca}^{2+}$. Solutions were equilibrated with $\mathrm{CO}_{2}$ at 1.0 atm with $\mathrm{CaCl}_{2}$ concentrations varied from 0.001 to $1 \mathrm{M}$ and $\mathrm{NaCl}$ concentrations at $0.1,0.5$ and $1.0 \mathrm{M}$.

\section{Fixed Bed Ion-Exchange Experiments}

An IEX column apparatus was constructed to study the dynamic ion exchange performance for the IEX materials. A schematic of the apparatus is shown in Supplementary Figure S1. Liquid feed was introduced into a glass tube $(3.5 \mathrm{~cm}$ inner diameter) using a BioLogic LP peristaltic pump. Fixed beds of IEX material (performed using bed volumes of $134.7 \mathrm{~cm}^{3}$ [14 cm height] unless otherwise stated) were held in place using quartz wool. Flow-rate studies using an inlet $\mathrm{CO}_{2}$-saturated solution $\left(\mathrm{pCO}_{2}=1.0 \mathrm{~atm}, \mathrm{pH} 3.9\right)$ were performed at 20, 40, 60, 120 and $160 \mathrm{~cm}^{3} \mathrm{~min}^{-1}$ (ccm) until the effluent $\mathrm{pH}$ (or cation concentration) was equivalent to that of the inlet. Effluent samples were collected at intervals of 5 min during the first hour and 30 min thereafter. Collected effluent samples were analyzed using a $\mathrm{pH}$ meter and ICP-OES. The breakthrough curves developed are presented as the normalized effluent $\mathrm{H}^{+}$concentration (Eq. 7) as a function of the number of normalized bed volumes (NBV) processed (Eq. 8). NBV is defined as liquid flowrate, Q $(\mathrm{ml} / \mathrm{min})$ divided by IEX material bed volume $\left(\mathrm{BV} ; \mathrm{cm}^{3}\right)$ multiplied by time, $\mathrm{t}(\mathrm{min})$.

$$
\begin{gathered}
\text { Normalized Effluent Concentration }=\frac{C_{\text {effluent }}}{C_{\text {inlet }}} \\
\mathrm{NBV}=\frac{\mathrm{Q} \cdot \mathrm{t}}{\mathrm{BV}}
\end{gathered}
$$

The effect of inlet $\mathrm{CO}_{2}$ concentrations on the $\mathrm{H}^{+}$exchange was performed using TP-207 $\left(134.7 \mathrm{~cm}^{3} ; 14 \mathrm{~cm}\right.$ height; $\left.40 \mathrm{ccm}\right)$ at the following $\mathrm{CO}_{2}$ inlet concentrations: $1.0 \mathrm{~atm} / \mathrm{pH} 3.9,0.5 \mathrm{~atm} / \mathrm{pH}$ 
4.1, $0.25 \mathrm{~atm} / \mathrm{pH} \quad 4.2$ and $0.1 .0 \mathrm{~atm} / \mathrm{pH}$ 4.4. Samples were collected at the same intervals described previously and analyzed using a $\mathrm{pH}$ meter and ICP-OES.

\section{Regeneration Experiments}

Regeneration of IEX materials was performed using 0.001, 0.010, 0.10 , and $1 \mathrm{M} \mathrm{NaCl}$ solutions. Regeneration efficiency (RE) of IEX materials is defined by:

$$
\mathrm{RE}=\left(1-\frac{\mathrm{EC}_{\mathrm{H}}-\mathrm{EC}_{\mathrm{Na}}}{\mathrm{EC}_{\mathrm{H}}}\right) \times 100
$$

where $\mathrm{EC}_{\mathrm{H}}$ and $\mathrm{EC}_{\mathrm{Na}}$ are the exchange capacities of $\mathrm{H}^{+}$and $\mathrm{Na}^{+}$, respectively, determined from single component exchange experiments. Fixed-bed IEX regeneration experiments $\left(12.4 \mathrm{~cm}^{3} ; 1.5 \mathrm{~cm}\right.$ inner diameter and $7 \mathrm{~cm}$ bed length; 40 $\mathrm{ccm}$ ) were performed using an inlet $\mathrm{CO}_{2}$-saturated solution $\left(\mathrm{pCO}_{2}=1.0 \mathrm{~atm}, \mathrm{pH} 3.9\right)$ to exhaust the column to the saturation limit and subsequently regenerated using an inlet solution composed of $0.7 \mathrm{M} \mathrm{NaCl}$ at $\mathrm{pH} 9.9$ (representative of the solution composition following mineralization in this process). Three cycles were performed for each IEX material used in this study.

\section{Analytical Models for Dynamic Ion-Exchange Processes}

Mathematical models that relate the properties of the material and the experimental conditions to the concentration-time profiles in the effluent of a fixed bed (i.e., a breakthrough curve) were used to quantify the rate and maximum exchange capacity from dynamic IEX experiments. Combining the partial differential equation that arises from the mass balance on the cation in a fixed bed with an ordinary differential equation that represents a linear exchange rate leads to a simple, two parameter equation [the exchange rate parameter $(\mathrm{kK})$ and the maximum exchange capacity $\left(q_{s}\right)$ ] that describes the breakthrough curve (see the SI for the detailed derivation). These parameters can be regressed from breakthrough curve data using nonlinear least squares fitting (Chowdhury et al., 2014).

The rate parameter $(\mathrm{kK})$ reflects resistance to exchange at three length scales: 1) diffusion of cations in the bulk liquid phase to the solid surface, 2) diffusion within solid phase pores, and 3) ion exchange at the anionic site. Diffusion resistances can be determined from known engineering correlations [see SI (IEA, 2019; IEA, 2020a)], and these resistances can be summed in series (similar to electrical resistances) according to Eq. 10 (Ruthven, 1984):

$$
\frac{1}{k K}=\frac{R_{p}}{3 k_{f}}+\frac{R_{p}^{2}}{15 \varepsilon_{p} D_{p}}+\frac{1}{k_{e x}}
$$

where $R_{p}$ is the radius of the ion exchanger particles, $D_{p}$ is the effective diffusivity of the incoming cation inside the pores of the solids, $k_{f}$ is the mass transfer coefficient for fluid film mass, $k_{e x}$ rate of exchange at the anionic site, and $\varepsilon_{p}$ is the porosity of the solid particles. The distribution parameter $(K)$ is the ratio of the concentration of the cation in the solid phase to that in the fluid phase at equilibrium.

\section{Carbon Dioxide Mineralization Using Simulated Produced Water and Ion Exchange Solutions}

$\mathrm{CO}_{2}$ mineralization experiments were performed using the effluents collected from dynamic IEX experiments described in Fixed Bed Ion-Exchange Experiments. Simulated produced water samples (see Supplementary Table S9 for compositions) were mixed with IEX effluents at varying volume ratios within a $1 \mathrm{~L}$ beaker, and solid precipitates were collected after $6 \mathrm{~h}$. Volume ratios, $V_{R}$, are defined as:

$$
V_{R}=V_{P W} /\left(V_{P W}+V_{I E X}\right)
$$

where $V_{\text {IEX }}$ represents the volume of IEX solution of the effluent stream from the IEX column and $V_{P W}$ represents the volume of simulated PW.

The IEX effluent and produced water solutions were continuously stirred for $4 \mathrm{~h}$ to ensure the $\mathrm{CO}_{2}$ mineralization reaction had occurred. After precipitation, two separate samples of the supernatant were analyzed via ICP-OES and $\mathrm{pH}$ measurements. Both samples were filtered through a 0.2 -micron Corning filter and the ICP-OES sample was diluted in $5 \%(\mathrm{w} / \mathrm{w})$ $\mathrm{HNO}_{3}$ (prepared by diluting $70 \% \mathrm{HNO}_{3}$ in ultra-pure water). The solid was collected from the solution via vacuum filtration and dried at $60{ }^{\circ} \mathrm{C}$ for $24 \mathrm{~h}$ prior to analysis. Powder X-ray diffraction (XRD) patterns of the precipitated phases were obtained on an X-Ray diffractometer (Panalytical X'Pert Pro $\mathrm{X}$-ray Powder Diffractometer) using $\mathrm{Cu} \mathrm{Ka}$ radiation of $1.5410 \AA$ to identify the phases in the precipitated solids. Scanning electron microscopy (SEM; Nova 230; $5 \mathrm{kV}$ accelerating voltage and a working distance of $5 \mathrm{~mm}$ ) and EDS was used to quantify elemental composition at the surface of the solids.

\section{Thermodynamic Modeling of Precipitation Products}

The activities and speciation of aqueous components were calculated using GEMSelektor, version 3.4, which includes a native GEM (Gibbs energy minimization) solver (Kulik et al., 2012; Wagner et al., 2012), a built-in NAGRA-PSI "Kernel”, and the slop98.dat and Cemdata18 thermodynamic databases (Johnson et al., 1992; Hummel et al., 2002; Thoenen et al., 2007; Lothenbach et al., 2019). Thermodynamic data for the solid phases are shown in Supplementary Table S10, and thermodynamic data for aqueous species/complexes and gases are shown in Supplementary Tables S11, S12, respectively. Thermodynamic data for nesquehonite $\left(\mathrm{MgCO}_{3} 3 \mathrm{H}_{2} \mathrm{O}\right)$ (Robie and Hemingway, 1995), hydromagnesite $\left(\mathrm{Mg}_{5}\left(\mathrm{CO}_{3}\right)_{4}(\mathrm{OH})_{2} \cdot 4 \mathrm{H}_{2} \mathrm{O}\right)$ (Galvez-Martos et al., 2018), dolomite $\left(\left(\mathrm{Ca}_{0.5} \mathrm{Mg}_{0.5}\right) \mathrm{CO}_{3}\right)$ (Galvez-Martos et al., 2018), monohydrocalcite $\left(\mathrm{CaCO}_{3} \cdot \mathrm{H}_{2} \mathrm{O}\right)$ (Robie and Hemingway, 1995), and an iron-calcium carbonate solid-solution model $\left((\mathrm{Ca}, \mathrm{Fe}) \mathrm{CO}_{3}\right)$ (Di Lorenzo et al., 2017) were included in the simulations. Thermodynamic data for metastable nesquehonite and hydromagnesite were included as potential magnesium carbonate phases, opposed to "natural" mineral thermodynamic data to represent the short-term precipitation time. The dolomite phase was chosen to represent 

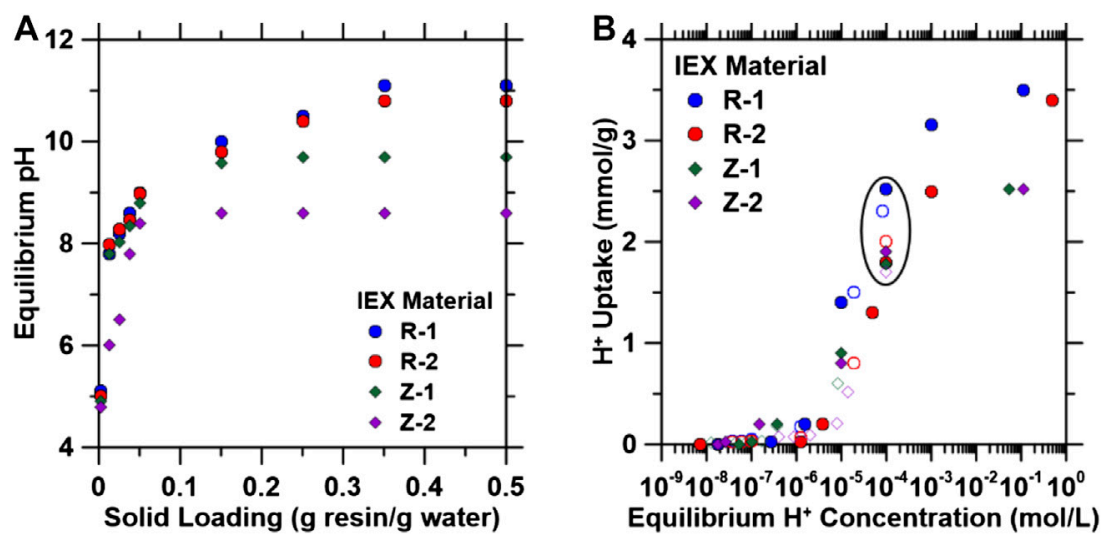

FIGURE 1 | (A) Changes in the $\mathrm{pH}$ of saturated carbon dioxide $\left(\mathrm{CO}_{2}\right)$ solutions $\left(\mathrm{pCO}_{2}=1.0\right.$ atm; initial $\left.\mathrm{pH}=3.9\right)$ using various amounts of ion exchange (IEX) materials (i.e., $0.010-10 \mathrm{~g}$ of IEX material were added to $20 \mathrm{ml}$ of the $\mathrm{CO}_{2}$-saturated solution). (B) $\mathrm{H}^{+}$exchange isotherms for organic IEX resins and zeolites in $\mathrm{DI}$ water. Batch exchange experiments were conducted using $\mathrm{HCl}$ (closed symbols) and $\mathrm{CO}_{2}$ (open symbols) as a source of $\mathrm{H}^{+}$ions. $\mathrm{HCl}$ isotherms were developed by varying $\mathrm{HCl}$ concentrations from 0.001 to $1 \mathrm{M} . \mathrm{CO}_{2}$ isotherms were developed by varying mass load at fixed volume of carbonated water at initial pCO $2=1.0$ atm. Circled area represents the equilibrium $\mathrm{H}^{+}$capacities at $10^{-4} \mathrm{M} \mathrm{H}^{+}\left(\mathrm{pH} \sim 3.9\right.$, similar to $\mathrm{CO}_{2}$ saturated water).

partial calcium replacement by magnesium within $\mathrm{CaCO}_{3}$. The $(\mathrm{Ca}, \mathrm{Fe}) \mathrm{CO}_{3}$ non-ideal solution model was developed in a $\mathrm{CaO}-$ $\mathrm{MgO}-\mathrm{FeOOH}-\mathrm{CO}_{2}$ system to represent iron (II) replacement within the $\mathrm{CaCO}_{3}$ structure in the presence of magnesium (Di Lorenzo et al., 2017).

The activity of any relevant ion species is described within GEMS using the Truesdell-Jones modification of the extended Debye-Hückel equation that is applicable for ionic strengths ( $I$, mol/L) less than $2 \mathrm{~mol} / \mathrm{L}$ (see Eq. 12) (Helgeson et al., 1981):

$$
\log \gamma_{i}=\frac{-A z_{i}^{2} \sqrt{I}}{1+\dot{a} B \sqrt{I}}+b_{\gamma} I+\log \frac{X_{j w}}{X_{w}}
$$

where, $\gamma_{i}$ and $z_{i}$ are the activity coefficient and charge of the $i^{\text {th }}$ aqueous species respectively, $A$ and $B$ are temperature- and pressure-dependent coefficients, $I$ is the molar ionic strength, $X_{j w}$ is the molar quantity of water, and $X_{w}$ is the total molar amount of the aqueous phase. A common ion size parameter, $\dot{a}$ $(3.72 \AA)$ and short-range interaction parameter, $b_{\gamma}$ $\left(0.064 \mathrm{~kg} \mathrm{~mol}^{-1}\right)$, are used as constants for the $\mathrm{NaCl}$ background electrolyte (Helgeson et al., 1981). $\mathrm{NaCl}$ was selected as the dominant electrolyte throughout this study to simulate the IEX product solution compositions and $\mathrm{pH}$ shown in Supplementary Table S8 because of constantly larger $\mathrm{NaCl}$ concentration in solution. Solution compositions in the simulations used the $V_{R}$ ratios as described by Eq. 11 using the solutions shown in Supplementary Tables S8-S9.

\section{RESULTS AND DISCUSSION}

\section{Non-competitive $\mathrm{H}^{+}$and $\mathrm{Na}^{+}$Uptake from DI Water}

To demonstrate the feasibility of $\mathrm{pH}$ shift using TP-207 (R-1), TP-260 (R-2), 4A (Z-1), and 13X (Z-2), increasing amounts of these materials were added to $20 \mathrm{ml}$ of $\mathrm{CO}_{2}$-saturated DI water $\left(\mathrm{pCO}_{2}=1.0\right.$ atm; $\left.\mathrm{pH}=3.9\right) .13 \mathrm{X}$ and $4 \mathrm{~A}$ exhibited maximum $\mathrm{pH}$ increases to 8.8 and 9.8 , respectively, at solid loading ratios of $0.15 \mathrm{~g} / \mathrm{g}$, while the two organic resins increased the solution $\mathrm{pH}$ to $\sim 11$ at ratios of 0.35 (Figure 1A) within $48 \mathrm{~h}$ (Supplementary Figure S2). To further quantify the maximum $\mathrm{H}^{+}$exchange (i.e., non-competitive) at equilibrium $\mathrm{pH}$ values similar to those for a $\mathrm{CO}_{2}$-saturated solution $(\mathrm{pH} \sim 4), \mathrm{H}^{+}-\mathrm{Na}^{+}$ exchange isotherms (Figure 1B) were collected for the resins and zeolites in DI water. Exchange isotherms were the same using $\mathrm{HCl}$ and $\mathrm{CO}_{2}$-saturated solutions, indicating that there is negligible counter ion (i.e., $\mathrm{Cl}^{-}, \mathrm{HCO}_{3}{ }^{-}$or $\mathrm{CO}_{3}{ }^{2-}$ ) effect. $\mathrm{H}^{+}$ exchange capacities at solution equilibrium concentrations of $10^{-4} \mathrm{M} \mathrm{H}^{+}$( $\mathrm{pH} \sim 3.9$, similar to $\mathrm{CO}_{2}$-saturated water) range from 1.7 to $2.4 \mathrm{mmol} \mathrm{H}^{+}$(g material) $^{-1}$ (circled in Figure 1B), with the organic resins exhibiting higher uptake capacities than the zeolites under more acidic solutions $\left(\mathrm{pH}<4\right.$; $\left.\left[\mathrm{H}^{+}\right]>10^{-4} \mathrm{M}\right)$. These data demonstrate the ability of these ion exchange materials to sufficiently shift the $\mathrm{pH}$ of aqueous solutions to conditions that favor carbonate precipitation (i.e., $\mathrm{pH}$ from 3.9 to $>10$ ) via compact flow processes (i.e., $50 \mathrm{~g}$ of material required to increase the $\mathrm{pH}$ of $1 \mathrm{~L}$ of water from 4 to 10 ; described in more detail in Dynamic Ion Exchange).

$\mathrm{Na}^{+}$exchange experiments were subsequently performed on the materials tested in Figure 1 using 0.001-1 M NaCl solutions to probe the reversibility (i.e., regeneration) of this exchange. $\mathrm{Na}^{+}$ exchange isotherms (Figure 2A) exhibit similar forms as $\mathrm{H}^{+}$ exchange isotherms, with maximum regeneration capacity achieved at $\mathrm{Na}^{+}$concentrations greater than $0.1 \mathrm{M}$. To quantify the extent of regeneration, materials at the $10^{-4} \mathrm{M}$ concentration point on the isotherms in Figure $\mathbf{1 B}$ were subsequently exposed to $1 \mathrm{M} \mathrm{NaCl}$ solutions [i.e., the typical minimum concentration in produced and waste water streams (Blondes et al., 2018)], and the $\mathrm{H}^{+}$and $\mathrm{Na}^{+}$exchange capacities of these materials are shown in Figure 2B, indicating near complete reversibility of the exchange. Regeneration efficiencies were calculated from these values (using Eq. 9), and for all exchange materials, $>95 \%$ regeneration was achieved. Multi- 

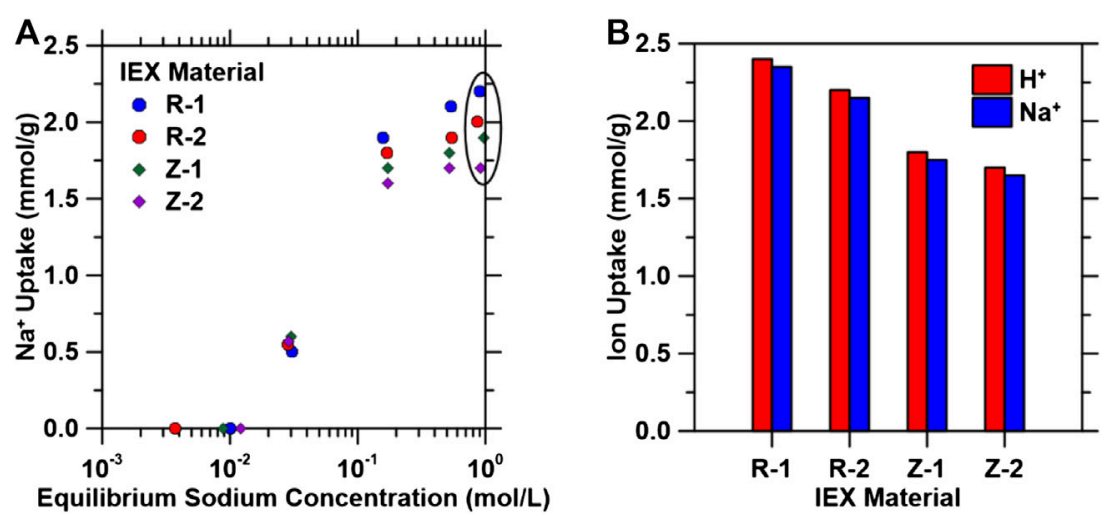

FIGURE 2 | (A) Regeneration isotherms of ion exchange materials using initial $\left[\mathrm{H}^{+}\right]$of $10^{-4} \mathrm{M}$ at varying equilibrium $\mathrm{NaCl}$ concentrations within the range $0.001<$ $[\mathrm{NaCl}]<1 \mathrm{M}$. (B) lon exchange capacities for $\mathrm{H}^{+}$(in equilibrium with $10^{-4} \mathrm{M} \mathrm{H}^{+}$in solution) and $\mathrm{Na}^{+}$(in equilibrium with $1 \mathrm{M} \mathrm{NaCl}$ in solution) ions for the four ion exchange materials used in this study. Circled area in (A) represents the equilibrium $\mathrm{Na}^{+}$capacities at $1 \mathrm{M} \mathrm{Na}^{+}$, where maximum uptake was observed.
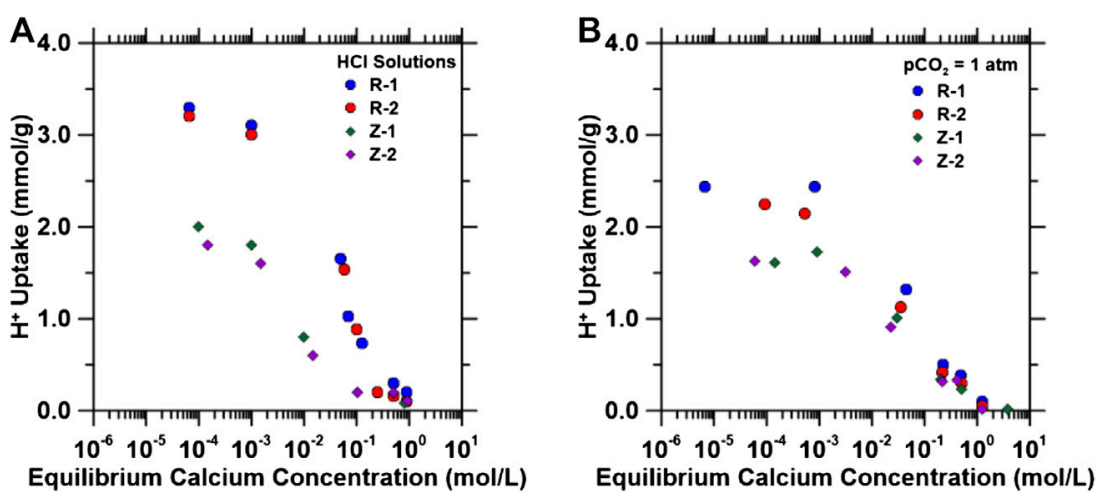

FIGURE 3 $\mathrm{H}^{+}$capacity as a function of equilibrium calcium concentrations $\left(0.001-1.0 \mathrm{M} \mathrm{CaCl}_{2}\right)$ in solution in (A) $1 \mathrm{~mol} / \mathrm{L} \mathrm{HCl}$ for resins, $0.1 \mathrm{~mol} / \mathrm{L} \mathrm{HCl} \mathrm{for} \mathrm{zeolites,}$ and (B) aqueous solutions equilibrated with $\mathrm{pCO}_{2}=1.0$ atm (initial $\mathrm{pH}=3.9$ ) using a solid/liquid ratio of $0.003 \mathrm{~g} / \mathrm{ml}$.

cycle experiments under flowing conditions (described in Regeneration Experiments) were conducted to further quantify the regenerability and stability of these IEX materials. Thus, the results indicate that these IEX materials are promising candidates for the regenerable $\mathrm{pH}$ shift process presented herein and that they can be regenerated using industrial wastewater streams (e.g., produced water).

\section{Competitive Ion Exchange}

\section{Competitive Exchange Between $\mathrm{H}^{+}$and $\mathrm{Ca}^{2+}$}

Industrial produced water typically contains a variety of ions [in particular, $\mathrm{Ca}$ and $\mathrm{Mg}$ at 0.1 and $0.05 \mathrm{M}$ respectively (Blondes et al., 2018)]. The organic cation exchange resins used in this study have a high affinity for divalent cations because of the chelating-like functional groups, as they are commonly used for water hardness removal (i.e., removal of $\mathrm{Ca}$ and $\mathrm{Mg}$ ions from water) (Dinu and Dragan, 2008). Similarly, the zeolites used in this study readily exchange cationic species (e.g., exchange of $\mathrm{Na}^{+}$ with $\mathrm{Ca}^{2+}$ leads to the formation of zeolite Type $5 \mathrm{~A}$ from $4 \mathrm{~A}$ )
(Breck, 1974). Thus, these affinities for divalent cations may hinder $\mathrm{Na}^{+}$and $\mathrm{H}^{+}$uptake when using a produced water feed for the $\mathrm{pH}$ shift process, so binary component IEX isotherms were generated (Figures 3A,B) using $0.01-1 \mathrm{M} \mathrm{CaCl}_{2}$ solutions with fixed initial $\mathrm{HCl}(1 \mathrm{M}$ for resins, $0.1 \mathrm{M}$ for zeolites to avoid dissolution) or $\mathrm{CO}_{2}$ (equilibration with $\mathrm{pCO}_{2}=1.0$ atm, $\mathrm{pH}=$ 3.9) concentrations to quantify the effect of $\mathrm{Ca}^{2+}$ exchange on $\mathrm{H}^{+}$ uptake capacity. As shown in Figures $3 \mathbf{A}, \mathbf{B}, \mathrm{H}^{+}$uptake decreased (and final $\mathrm{pH}$ decreased; Supplementary Figure S3) with increasing equilibrium calcium concentrations for all materials. These results indicate that a $\mathrm{pH}$ swing process using the materials studied herein requires $\mathrm{pH}$ shift of a $\mathrm{Ca} / \mathrm{Mg}$ depleted stream with subsequent mixing with $\mathrm{PW}$ in a separate precipitation reactor (as described subsequently in Carbon Dioxide Mineralization of Simulated Produced Water and Ion Exchange Solutions).

Competitive Exchange Between $\mathrm{Na}^{+}$and $\mathrm{Ca}^{2+}$ or $\mathrm{Mg}^{2+}$ Selectivity of IEX materials for divalent cations over monovalent cations during the regeneration step was further probed using a 

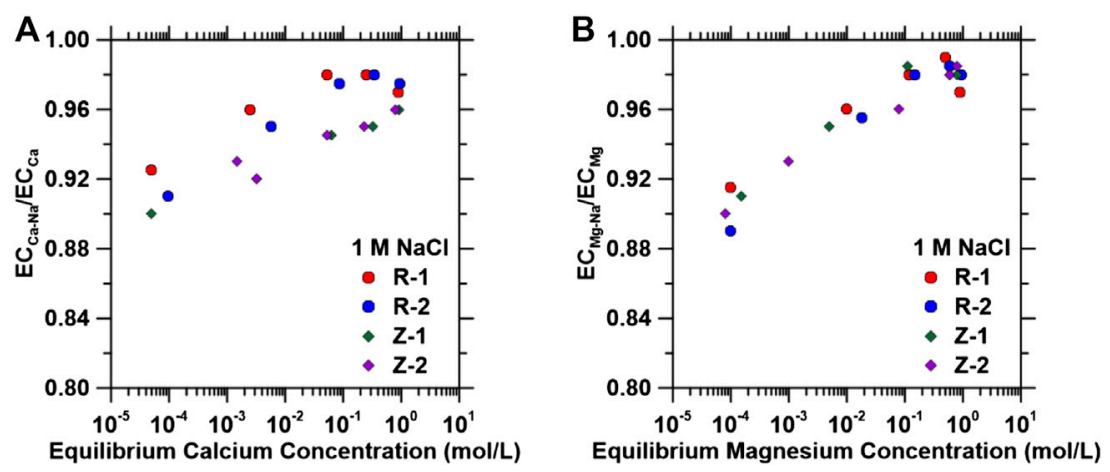

FIGURE 4 | Effect of $1 \mathrm{M} \mathrm{NaCl}$ on $\mathbf{( A )}$ calcium and $\mathbf{( B )}$ magnesium normalized exchange capacities of ion exchange materials as a function of equilibrium concentrations.
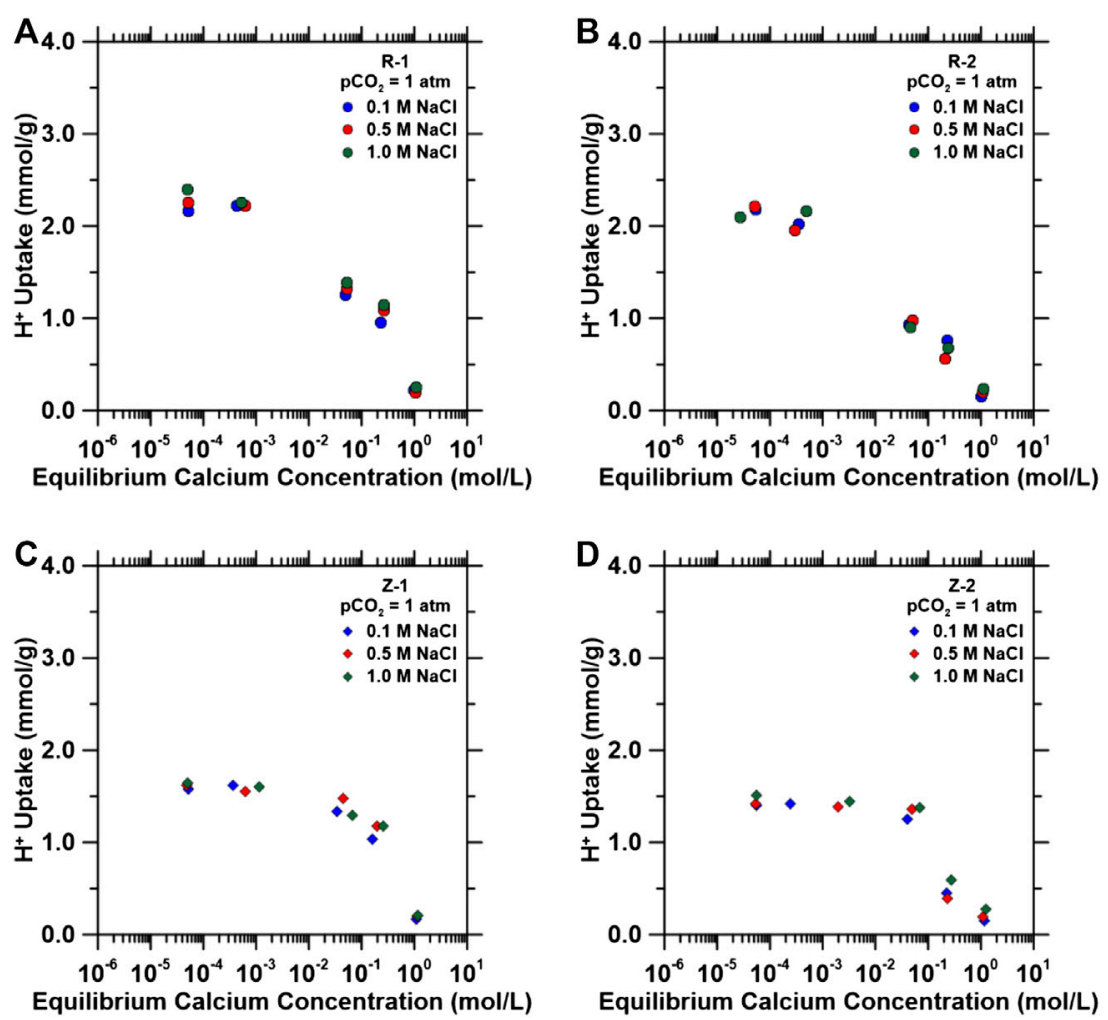

FIGURE 5 $\mid \mathrm{H}^{+}$inhibition in ternary systems composed of fixed $\mathrm{pCO}_{2}=1.0 \mathrm{~atm}$ and variable $\mathrm{NaCl}$ concentration as a function of equilibrium calcium concentration in solution for (A) R-1, (B) R-2, (C) Z-1 and (D) Z-2. $\mathrm{H}^{+}$uptake capacities were quantified using varying $\mathrm{CaCl}_{2}$ solutions $(0.01-1 \mathrm{M})$, fixed $\mathrm{pCO} \mathrm{C}_{2}=1.0$ atm, and varying background $\mathrm{NaCl}$ solutions $(0.1-1 \mathrm{M})$. Background $\mathrm{NaCl}$ concentrations remained the same in solution before and after $\mathrm{H}^{+}$exchange.

binary mixture of $\mathrm{NaCl}-\mathrm{CaCl}_{2}$ and $\mathrm{NaCl}-\mathrm{MgCl}_{2}$. These solutions contained a fixed concentration of $1 \mathrm{M} \mathrm{NaCl}$ and $\mathrm{CaCl}_{2}$ or $\mathrm{MgCl}_{2}$ concentrations in a range from 0.001 to $1 \mathrm{M}$. Supplementary Figures S4A,B show the single component calcium and magnesium isotherms, respectively. Figures $4 \mathbf{A}, \mathbf{B}$ shows the ratio of the exchange capacity (Eq. 6) for $\mathrm{Ca}$ and $\mathrm{Mg}$ in the presence of $1 \mathrm{M} \mathrm{NaCl}\left(\mathrm{EC}_{\mathrm{Ca}-\mathrm{Na}}\right.$ and $\left.\mathrm{EC}_{\mathrm{Mg}-\mathrm{Na}}\right)$ to that for single component $\mathrm{Ca}$ and $\mathrm{Mg}$ exchange $\left(\mathrm{EC}_{\mathrm{Ca}}\right.$ and $\left.\mathrm{EC}_{\mathrm{Mg}}\right)$. These exchange capacity ratios are $>0.9$ across the entire experimentally tested range and approach 1.0 for concentrations of $\mathrm{Mg}$ and $\mathrm{Ca}$ found in typical $\mathrm{PW}$. At ambient temperature and low concentrations of cations, the extent of exchange is a function of ion's valence, radius, and activity. However, at a higher concentration of the incoming cation, the effect of valence in ion exchange is weakened, and ions with lower valence have higher exchange potential (Wachinski, 2017). As shown in Figure 4, IEX material regeneration must be accomplished with PW that is deficient of divalent cations due to the larger divalent cation uptake. 


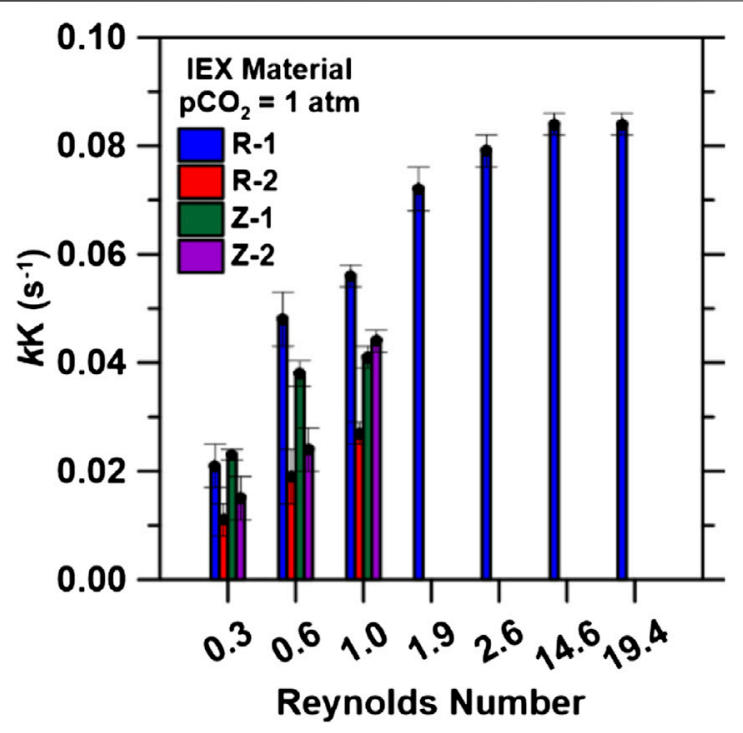

FIGURE 6 | Regressed rate parameters, $k \mathrm{~K}\left(\mathrm{~s}^{-1}\right)$, using inlet $\mathrm{pCO}_{2}=$ $1.0 \mathrm{~atm}$ at all inlet flow rates. Bed volumes of $134.7 \mathrm{~cm}^{3}(3.5 \mathrm{~cm}$ column diameter) were used for Reynolds numbers 0.3-1.0. Bed volume was increased to $279 \mathrm{~cm}^{3}$ ( $3.5 \mathrm{~cm}$ column diameter) for Reynolds numbers 1.9 to 2.6. Bed volume of $51.2 \mathrm{~cm}^{3}$ (1.27 cm column diameter) was used for Reynold numbers 14.6 and 19.4 .

\section{$\mathrm{H}^{+}$Exchange in the Presence of $\mathrm{Na}^{+}$and $\mathrm{Ca}^{2+}$}

The effect on $\mathrm{H}^{+}$uptake capacity in a ternary system composed of $\mathrm{CO}_{2}-\mathrm{NaCl}-\mathrm{CaCl}_{2}$ was quantified to examine the effect of high $\mathrm{NaCl}$ concentrations on the $\mathrm{H}^{+}$capacities. In systems containing large $\mathrm{NaCl}$ concentrations and small $\mathrm{CaCl}_{2}$ concentrations (i.e., typical produced waters), $\mathrm{Ca}^{2+}$ cation uptake may be inhibited because of the larger concentration gradient of the monovalent cations present (Galvez-Martos et al., 2018). Figure 5 shows the effect of $\mathrm{Ca}^{2+}$ on $\mathrm{H}^{+}$capacities.

For each material and consistent with the results shown in Competitive Exchange Between $\mathrm{H}^{+}$and $\mathrm{Ca}^{2+}$, increasing equilibrium calcium concentrations decreases $\mathrm{H}^{+}$uptake despite the additional presence of background $\mathrm{Na}^{+}$cations in solution. Both types of materials exhibited similar divalent cation uptake, and, in this regard, there is no clear advantage to choose one material over another.

These results confirm the requirement of removal of divalent cations from $\mathrm{PW}$ prior to the $\mathrm{pH}$ shift step. In the overall process (as later described in Process Design), produced water streams will be mixed with basic $(\mathrm{pH}>10), \mathrm{CO}_{2}$-saturated effluents from the IEX columns to induce precipitation of $\mathrm{CaCO}_{3}$. The residual liquid after precipitation, which is rich in $\mathrm{Na}$ and $\mathrm{Mg}$ but depleted of $\mathrm{Ca}$, will be processed via nanofiltration and reverse osmosis to remove $\mathrm{Mg}$ and produce a Na-rich stream for IEX column regeneration. The Na-depleted stream from the effluent of regeneration can then be saturated with $\mathrm{CO}_{2}$ for the $\mathrm{pH}$ swing process to produce alkaline solutions for precipitation. Thus, this configuration ensures utilization of the entire PW stream while minimizing the need for fresh DI water streams.

\section{Dynamic lon Exchange}

Fixed bed exchange experiments were conducted to determine the impact of transport phenomena on exchange capacities and to quantify exchange rates so that IEX columns can be sized for various process conditions (e.g., column contact times and feed $\mathrm{pH})$. The performance of the fixed-bed columns (i.e., determination of parameters $k K$ and $q_{s}$ ) were quantified using the LDF models described in Fixed Bed Ion-Exchange Experiments (and in the SI). The breakthrough curves (Supplementary Figures S4-S6; Figure 6) are presented as the normalized effluent $\mathrm{H}^{+}$concentration as a function of the number of NBV as defined in Fixed Bed Ion-Exchange Experiments (Eq. 8).

Effects of Flowrate on $\mathrm{H}^{+}$Uptake Capacities and Rates Flowrate is an important parameter to evaluate the efficiency of ion exchange materials in a continuous process because contact time and column hydrodynamics [i.e., Reynolds number (Re)] can impact IEX capacities and rates (Cooper, 1965; Barros et al., 2004; Borba et al., 2006; Chatterjee et al., 2018). The effect of varying flow rate on $\mathrm{H}^{+}$saturation capacities and ion exchange rate parameters were probed using saturated $\mathrm{CO}_{2}\left(1.0 \mathrm{~atm} \mathrm{CO}_{2}\right.$; $\mathrm{pH}=3.9)$ feed solutions at flow rates ranging from $20-160 \mathrm{ccm}$ (Re 0.3-19.4). Experimental saturation capacities were quantified when the outlet $\mathrm{H}^{+}$concentration was equivalent to $95 \%$ of the inlet $\mathrm{H}^{+}$concentration. The second order LDF model (Supplementary Equation S2) was used to quantify the rate parameter ( $k$ K in Eq. 10). (Bohart and Adams, 1920) IEX resins had larger capacities compared to zeolites, which is consistent with the exchange isotherms described previously. However, shown in Supplementary Figure S6, saturation capacities (mmol H $\mathrm{H}^{+} / \mathrm{g}$ ) achieved in the flow experiments (1.45 for R-1, $1.44 \mathrm{mmol} / \mathrm{g}$ for R-2, $0.91 \mathrm{mmol} / \mathrm{g}$ for Z-1 and $0.75 \mathrm{mmol} / \mathrm{g}$ for Z2 at $\mathrm{BV}=134.7 \mathrm{~cm}^{3}$ ) were lower compared to the equilibrium values determined from the isotherms (Figure 1B) and decreased with increasing inlet flow rate. It has previously been reported that increasing flow rates reduces contact times with the IEX solid resulting in decrease in saturation capacities (and smaller values compared to equilibrium capacities) because of insufficient diffusion of solute into the pores of the IEX solid, consequently limiting the number of active sites or ionic groups in contact with the solute for ion exchange (Baker et al., 1954; Aksu and Gönen, 2004; Han et al., 2006; ElKamash, 2008; El-Kamash, 2008; Mondal, 2009; Guo et al., 2013; Bhaumik et al., 2013; Jang and Lee, 2016; Malik et al., 2018).

Additional breakthrough tests (Supplementary Figure S5E,F) using bed volumes of $279 \mathrm{~cm}^{3}$ (height $29 \mathrm{~cm}$, diameter $3.5 \mathrm{~cm}$ ), $51.2 \mathrm{~cm}^{3}$ (height $29 \mathrm{~cm}$, diameter $1.27 \mathrm{~cm}$ ) and inlet flow rates of 120 and $160 \mathrm{ccm}$ for R-1 were conducted to probe the IEX process at higher $\operatorname{Re}(>1.0) . \operatorname{Re}=1.0(\sim 1.35)$ and $\operatorname{Re}=1.9$ ( 1.75). Increasing bed volume (from 134.7 to $279 \mathrm{~cm}^{3}$ for $\mathrm{Re}=1.9$ and 2.6) increased $\mathrm{H}^{+}$capacities to $1.71 \mathrm{mmol} / \mathrm{g}$ (Supplementary Figure S6), closer to its equilibrium capacity $(2.4 \mathrm{mmol} / \mathrm{g})$. This increase in saturation capacity can be explained by the increase in contact time and the expansion of the mass transfer zone due to the increase in ion exchange sites available along the larger bed length (Golie and Upadhyayula, 2016; Mazur et al., 


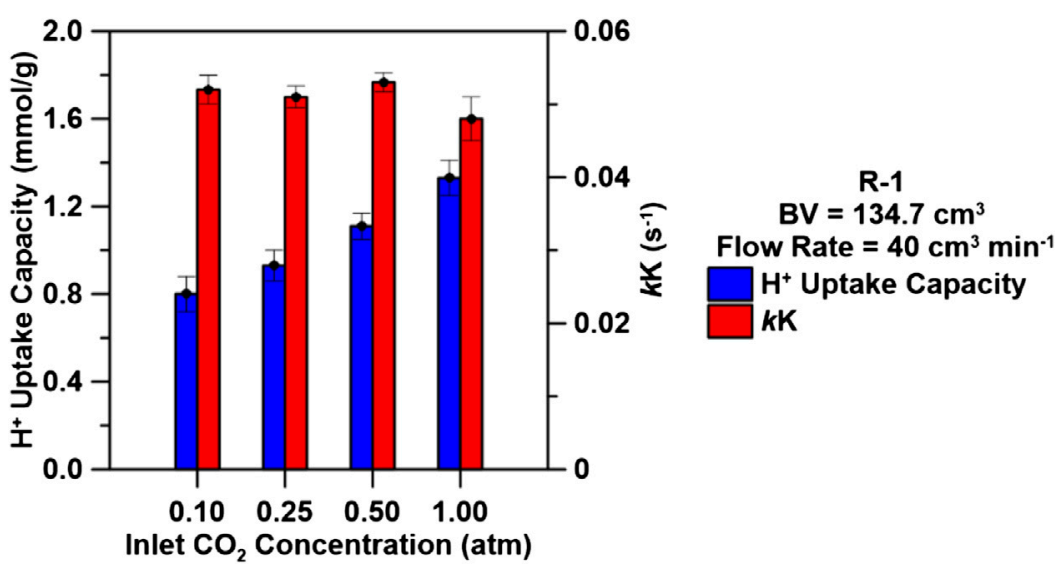

FIGURE $7 \mid \mathrm{H}^{+}$uptake capacities $(\mathrm{mmol} / \mathrm{g})$ and regressed rate parameter, $k \mathrm{~K},\left(\mathrm{~s}^{-1}\right)$ for $\mathrm{R}-1$ at varying carbon dioxide inlet concentrations using a bed volume of $134.7 \mathrm{~cm}^{3}$ and an inlet flow rate of $40 \mathrm{~cm}^{3} \mathrm{~min}^{-1}$.

2016; Chatterjee et al., 2018; Jin et al., 2018). Furthermore, as shown in Figure 7, increasing flowrate led to an increase in $k \mathrm{~K}$ for all materials. The regressed rate parameter increased significantly with an increase in flow rate $(20-60 \mathrm{ccm})$ from 0.021 to $0.056 \mathrm{~s}^{-1}$ for R-1, from 0.011 to $0.027 \mathrm{~s}^{-1}$ for R-2, 0.023 to $0.041 \mathrm{~s}^{-1}$ for Z-1 and 0.015 to $0.044 \mathrm{~s}^{-1}$ for Z-2, demonstrating the overall system kinetics is dominated by external mass transfer in the column (Aksu and Gönen, 2004; Ostroski et al., 2011; Bhaumik et al., 2013; Puerta-Falla et al., 2017; Gouran-Orimi et al., 2018). Under convective mixing, the ion-exchange rate increases as the mixing speed increases (in this case the flow rate), and the resistance of the boundary layer that surrounds the ion exchange materials weakens (Dyer and Gettins, 1970). When diffusion is the ratecontrolling step, then the rate-controlling diffusion process may not be within the micropores themselves but, instead, limited by the transport via a near-static boundary layer that is inserted between the external solution and the crystalline surface (Townsend, 1991). This process is described as a film or boundary-layer diffusion. However, increasing flow rates up to $160 \mathrm{ccm}$, from $60 \mathrm{ccm}$, for R-1 using $\mathrm{pCO}_{2}=1.0$ atm displayed minimal changes to the rate parameter $k \mathrm{~K}\left(\sim 0.075 \mathrm{~s}^{-1}\right)$, indicating decreased influence of film diffusion limitations. Additionally, increasing $\mathrm{Re}$ by reducing the column diameter at 120 and $160 \mathrm{ccm}$ ( $\operatorname{Re} 14.6$ and 19.4, respectively) showed no changes in the rate parameter $\left(0.084 \mathrm{~s}^{-1}\right)$. At this point, $k$ represents intraparticle diffusion rates that will define the kinetics of the IEX process and can be used to design the process at the appropriate flow rates as discussed in Process Design.

\section{Effect of Inlet Concentration on $\mathrm{H}^{+}$Uptake Capacities} $\mathrm{CO}_{2}$ concentrations by volume from point sources are about $3 \%$ for natural gas-fired power plants, $12 \%$ for coal-fired power plants and iron and steel mills, $20 \%$ for cement plants, and $>90 \%$ from ammonia, ethanol, and hydrogen plants (Florin et al., 2010). An increase in inlet concentrations for IEX processes lead to higher uptake capacities and faster breakthrough time because of the large concentration gradient produced (Chowdhury et al., 2014). Therefore, breakthrough curves at varying inlet $\mathrm{CO}_{2}$ concentrations $(0.10,0.25,0.50$, and $1.0 \mathrm{~atm} \mathrm{CO}_{2}$ ) were collected for R-1 IEX resin (the IEX material with the highest $\mathrm{H}^{+}$uptake capacity) to probe this effect under flowing conditions.

Breakthrough curves were collected for R-1 at $\mathrm{CO}_{2}$ concentrations from 0.10 to $1.0 \mathrm{~atm}(10-100 \%)$ to quantify its effect on saturation capacities and breakthrough time using an inlet flow rate of $40 \mathrm{ccm}$ and a bed volume of $134.7 \mathrm{~cm}^{3}$. The breakthrough time decreased as $\mathrm{CO}_{2}$ influent concentration increased from 0.10 to $1.0 \mathrm{~atm}$ and $\mathrm{H}^{+}$uptake capacities decreased with decreasing inlet $\mathrm{CO}_{2}$ concentrations, as shown in Supplementary Figure S7; Figure 8. The maximum uptake capacity was achieved using an initial $\mathrm{CO}_{2}$ concentration of $1.0 \mathrm{~atm}$ at $1.33 \mathrm{mmol} / \mathrm{g}$ with minimal changes to the kinetic rate parameter $k \mathrm{~K}\left(\sim 0.050 \mathrm{~s}^{-1}\right)$. The driving force for ion exchange is the concentration difference between the solute on the sorbent and the solute in the solution (Aksu and Gönen, 2004; El-Kamash, 2008; Bhaumik et al., 2013). A high concentration difference provides a high driving force for the ion exchange process, which may explain why higher $\mathrm{H}^{+}$uptake capacities were obtained using larger $\mathrm{CO}_{2}$ inlet concentrations. Additionally, at larger inlet $\mathrm{CO}_{2}$ concentrations, binding sites are rapidly filled with sorbate $\mathrm{H}^{+}$which results in a decrease in breakthrough time. Maximizing $\mathrm{H}^{+}$uptake capacities across all concentrations can be performed by increasing bed-depth as discussed in Effects of Flowrate on $\mathrm{H}^{+}$Uptake Capacities and Rates.

\section{Regeneration and Cycling of lon Exchange Materials} Cycle-to-cycle stability of IEX materials were studied via successive $\mathrm{H}^{+}-\mathrm{Na}^{+}$exchange cycles, as shown in Figure 6 (at $\mathrm{BV}$ of $12.4 \mathrm{~cm}^{3}$, flow rate of $40 \mathrm{ccm}, \mathrm{H}+$ exchange $\mathrm{pH}=3.9$, and $\mathrm{Na}+$ exchange inlet concentrations of $0.7 \mathrm{M} \mathrm{NaCl} / \mathrm{pH} 9.9$ ). Regeneration for all IEX materials was achieved within 100 normalized bed volumes for each cycle, when the effluent $\mathrm{pH}$ was equivalent to the inlet $\mathrm{pH}$, as shown in Supplementary Figure S8. Breakthrough curves for all three cycles for each IEX material are shown in Figure $\mathbf{6}$ with their respective exchange parameters shown in Supplementary Table S13. The 

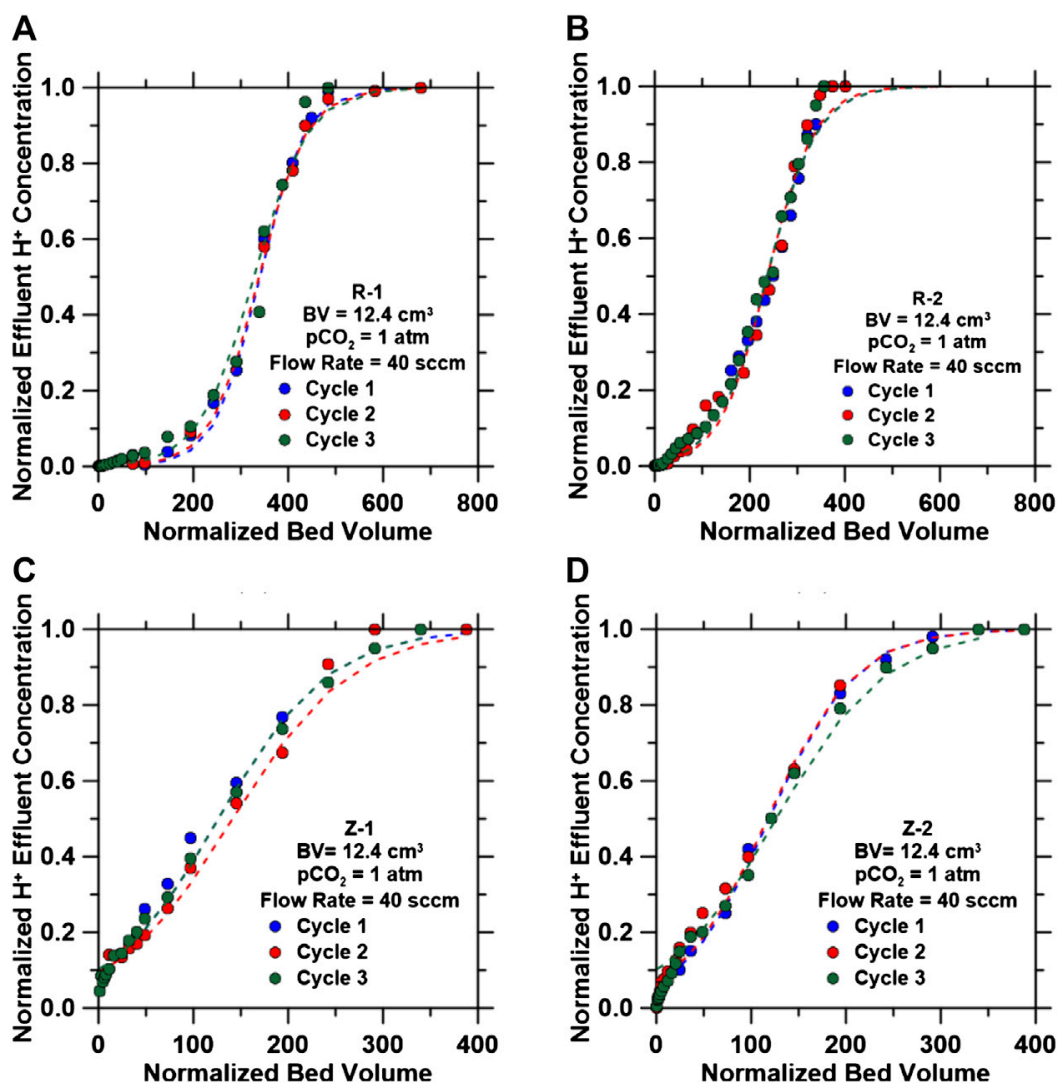

FIGURE 8 |Breakthrough curves for the $\mathrm{H}^{+}$exchange reaction for three cycles after regenerating with an inlet composition of $0.7 \mathrm{M}$ NaCl at a pH 9.9. Breakthrough curves developed using inlet flow rates of $40 \mathrm{ccm}$ and $\mathrm{pCO}_{2}=1.0$ atm for (A) R-1, (B) R-2, (C) Z-1 and (D) Z-2. Dashed lines represent Bohart-Adams model predictions for breakthrough curves.

breakthrough time for each material was almost constant for each of their respective cycles, resulting in identical $\mathrm{H}^{+}$uptake capacities and rate parameter $\mathrm{kK}$ values (Supplementary Table S13).

The four IEX materials studied displayed similar $\mathrm{H}^{+}$uptake capacities after three cycles using a regenerant feed composed of $0.7 \mathrm{M} \mathrm{NaCl}$ at a $\mathrm{pH} 9.9$, which is representative of the solution following the mineralization step of this process (discussed in Carbon Dioxide Mineralization of Simulated Produced Water and Ion Exchange Solutions). Regeneration time for the IEX resins can be reduced using higher $\mathrm{pH}$ solutions as is done industrially with caustic soda (Kunin and Vassiliou, 1963; Maul et al., 2014; VíctorOrtega et al., 2017). More cycles will be necessary to identify the point at which the IEX materials begin to reduce in $\mathrm{H}^{+}$uptake capacities.

\section{Carbon Dioxide Mineralization of Simulated Produced Water and Ion Exchange Solutions}

Simulated $\mathrm{CO}_{3}{ }^{2-}$-rich water with the same $\mathrm{Na}^{+}$and $\mathrm{CO}_{3}{ }^{2-}$ concentrations as the IEX columns was mixed with simulated produced water solutions at varying volumetric ratios, $V_{R}$ (Eq. 11). As shown in Supplementary Table S8, R-1 displayed a larger
$\mathrm{pH}$ swing, with a final solution $\mathrm{pH}$ 11.1, compared to the other IEX materials. Therefore, thermodynamic simulations were performed to predict phase formation and calcite yield using $\mathrm{R}-1$ compositions as a function of different volume fractions $\left(\mathrm{V}_{\mathrm{R}}\right)$, shown in Figure 9A.

As shown in Figure 9A, $\mathrm{CaCO}_{3}$ formation changes with varying volume ratio due to increasing $[\mathrm{Ca}]:\left[\mathrm{CO}_{2}\right]$ ratio in solution. $\mathrm{CaCO}_{3}$ formation is maximized when the $[\mathrm{Ca}]:\left[\mathrm{CO}_{2}\right]$ ratio was $1: 1$, which occurs at a $V_{R}$ of 0.23 . $R-1$ solutions produce the largest quantities of $\mathrm{CaCO}_{3}$ and highest purities of calcite as shown in Figures 9B,C, respectively, because of the higher initial $\mathrm{pH}$.

For zeolitic solutions, aragonite formation is dominant between volume ratios of $0.2-0.6$ because large $[\mathrm{Ca}] /[\mathrm{Fe}]$ ratios are required to favor calcite formation (Di Lorenzo et al., 2017), with goethite as the primary contaminant. The reduction of the initial $\mathrm{pH}$ reduces goethite formation which decreases the [Ca]/ $[\mathrm{Fe}]$ in solution to a point where it enters the miscibility gap of the (Fe,Ca) $\mathrm{CO}_{3}$ solid solution model used (Di Lorenzo et al., 2017). The $\mathrm{FeCO}_{3}$ end-member forms preferentially but at low quantities which causes aragonite to form in place of calcite. $\mathrm{CaCO}_{3}$ precipitation decreases at $\mathrm{V}_{\mathrm{R}}>0.25$ for ion exchange materials because of the lower initial $\mathrm{pH}$ and reduction of aqueous $\mathrm{CO}_{2}$, reducing the activity of $\mathrm{CO}_{3}{ }^{2-}$ in solution. 

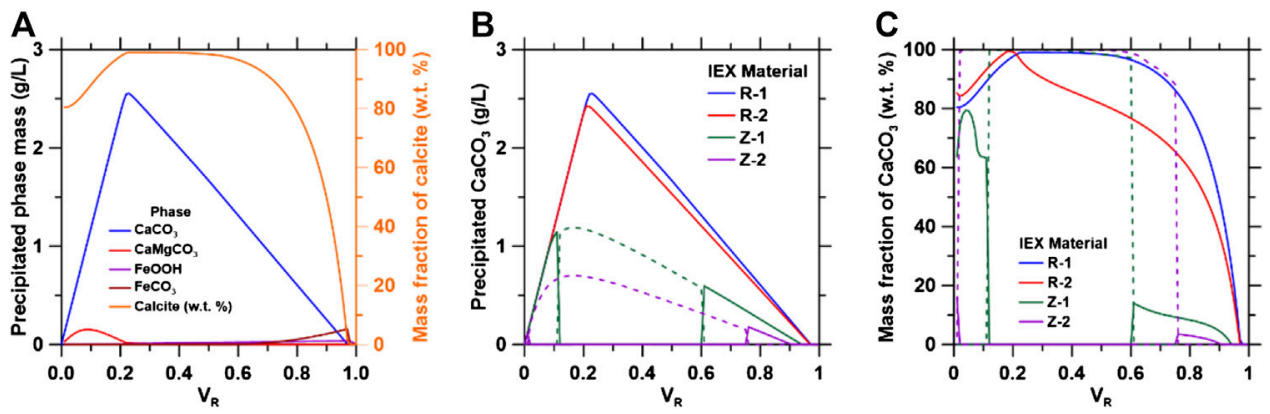

FIGURE 9 | (A) Simulated phase formation and purity of calcite in alkaline conditions; (B) $\mathrm{CaCO}_{3}$ formation and (C) purity of calcite formed as a function of varying volume fractions for the four ion exchange solutions studied. The dashed lines for zeolitic materials represent aragonite phase formation.

A

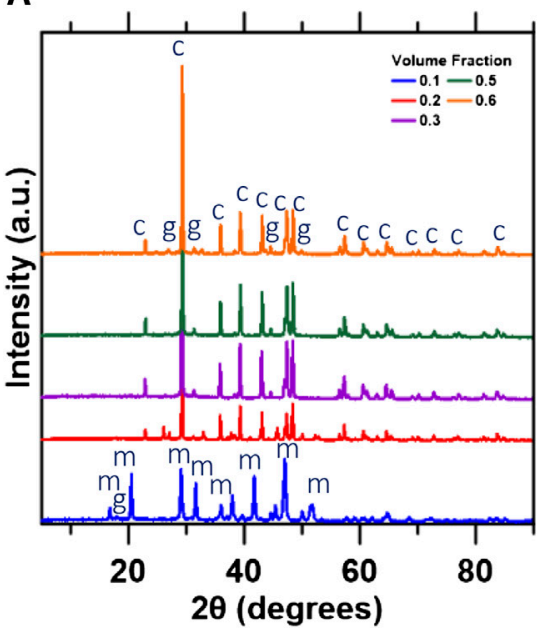

B

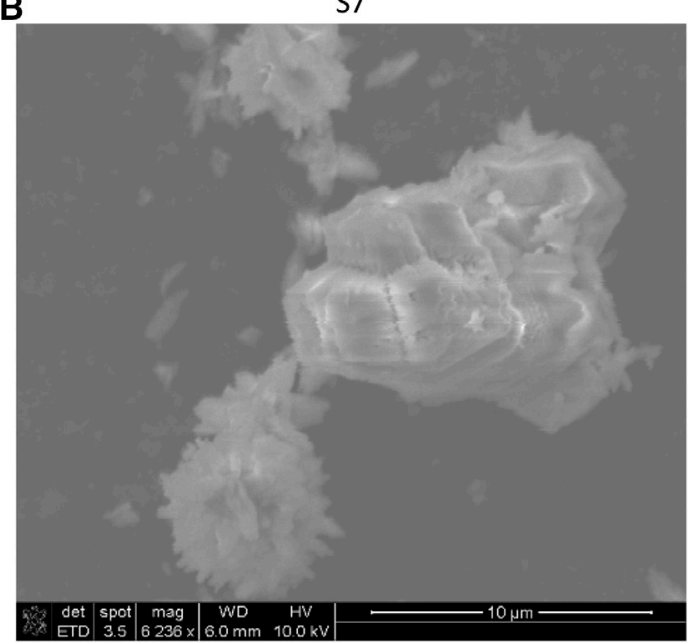

FIGURE 10 | (A) XRD diffraction patterns identifying present phases over varying volume ratios. c, calcite, g, goethite and m, monohydrocalcite; (B) SEM image of calcite synthesizes at a volume fraction of 0.7 .

To validate the thermodynamic simulations, experiments were performed using R-1 solutions because of the larger predicted mass and purity of $\mathrm{CaCO}_{3}$ precipitated. The dominant phase formed from volume fractions 0.2-0.6 was calcite with goethite as the primary contaminant as shown in the XRD patterns (Figure 10A). At $V_{R}=0.1$, monohydrocalcite (MHC) was the primary phase that formed during mineralization (Supplementary Figure S9A) as it requires a solution containing $[\mathrm{Mg}] /[\mathrm{Ca}]>0.2$ and $\left[\mathrm{CO}_{2}\right] /$ [Ca] > 1 to form (Nishiyama et al., 2013; Rodriguez-Blanco et al., 2014; Blue et al., 2017). When $\mathrm{V}_{\mathrm{R}}=0.1$, the $[\mathrm{Mg}] /[\mathrm{Ca}]$ and $\left[\mathrm{CO}_{2}\right] /[\mathrm{Ca}]$ were 0.44 and 2.54 , respectively, which are within the parameters required for $\mathrm{MHC}$ formation. At $\mathrm{V}_{\mathrm{R}}>$ 0.18 , the $\left[\mathrm{CO}_{2}\right] /[\mathrm{Ca}]<1.0$ thus, MHC did not form after this point.

The SEM image (Figure 10B) of calcite precipitated at $\mathrm{V}_{\mathrm{R}}=$ 0.3 displays the stable rhombohedral structure expected of calcite formation (Kralj et al., 2004). The rhombohedral structure was observed for $\mathrm{V}_{\mathrm{R}}$ values of 0.2-0.6. At $\mathrm{V}_{\mathrm{R}}=$ 0.1 , the stable rod-like structure for MHC was dominant, as shown in Supplementary Figure S9B. EDS analysis at the surface was performed to quantify $\mathrm{CaCO}_{3}$ purity. As shown in Supplementary Table S14, experimental results are consistent with thermodynamic simulations performed for across the volume fractions studied.

The experimental data and simulated mass balances showed good agreement. Simulated goethite was within 0.3 mass $\%$ of the experimental values throughout. Within the range $0.2<\mathrm{V}_{\mathrm{R}}<0.6$, simulated calcite was within 2 mass \% of the experimental values. Significant $\mathrm{CaCO}_{3}$ differences was observed for $\mathrm{V}_{\mathrm{R}}=0.1$ because simulations predicted 9.9 mass\% of potential $\mathrm{CaMgCO}_{3}$ phase formation. $\mathrm{CaMgCO}_{3}$ phases were not detected in XRD patterns across all volume ratios leading to differences in the mass of magnesium detected and simulated, implying either the small magnesium content is not detectable by $\mathrm{XRD}$ or the magnesium is adsorbed at the surface of the solid. 

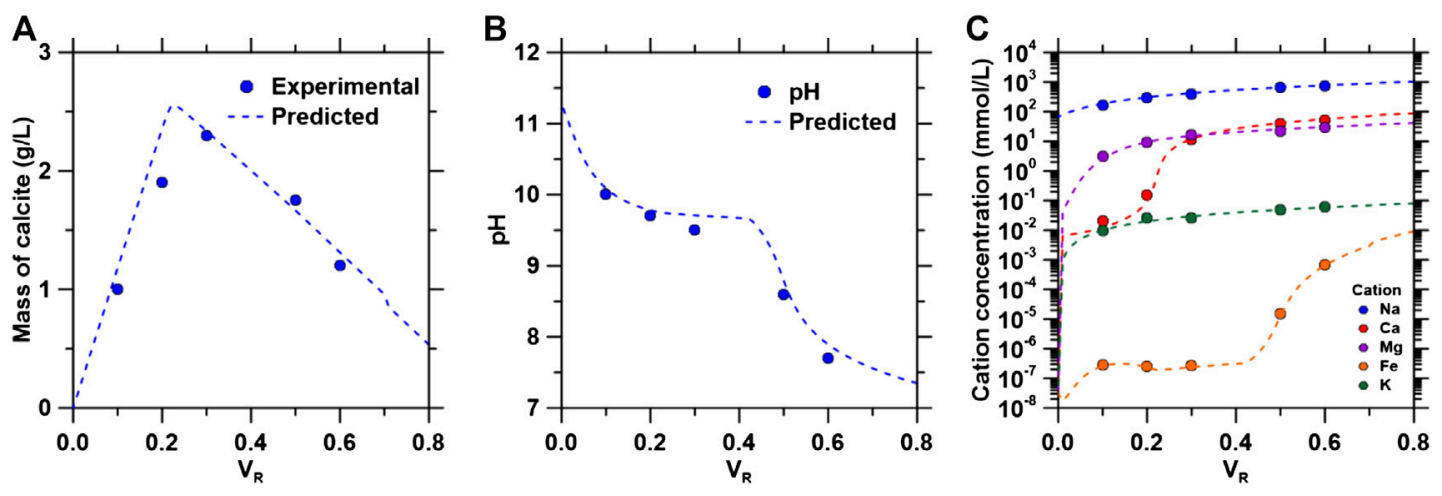

FIGURE 11 | (A) Yield of precipitated calcite, (B) final $\mathrm{pH}$ of solution after precipitation and (C) cation concentrations in solution following precipitation as a function of volume ratios. The "filled' circle represent experimental data and the dotted lines represent simulation results.

The precipitated mass of calcite increased and decreased, shown in Figure 11A, following the molar ratios of $[\mathrm{Ca}]:\left[\mathrm{CO}_{3}{ }^{2-}\right]$, where $<5 \%$ difference between simulated and experimental values were observed. The $\mathrm{pH}$ was observed to decrease as the $V_{R}$ increased as shown in Figure $11 B$, because of the increasing dilution of the alkaline IEX solution by produced water. The $\mathrm{pH}$ buffering effect of carbonate ions is observed up to $\mathrm{V}_{\mathrm{R}}=0.43$, where $\mathrm{pH}=9.6$. A significant drop in $\mathrm{pH}$ may be the result of increased goethite formation in the system, consuming additional $\left[\mathrm{OH}^{-}\right]$provided by the IEX column. Additionally, simulated $\mathrm{pH}$ values were in good agreement with the experimental results as they were within $0.1-0.3 \mathrm{pH}$ units. Concentrations of cations increased as the PW ratio increased, shown in Figure 11C. However, calcium concentrations observed a postponed rise due to calcite formation. Iron concentrations do not increase significantly until $\mathrm{V}_{\mathrm{R}}=0.46$. The available iron at $\mathrm{V}_{\mathrm{R}}<0.46$ was converted into goethite resulting in $[\mathrm{Fe}]<2.3 \times 10^{-6} \mathrm{mmol} /$ L. When $\mathrm{V}_{\mathrm{R}}>0.46$, the iron concentration rose rapidly due to decreasing $\left[\mathrm{OH}^{-}\right]$as the alkalinity provided by the IEX solution decreased. The accurate thermodynamic predictions shown from the experimental results and simulations are significant as they can further be used to predict phase formations and $\mathrm{CaCO}_{3}$ yields for the IEX process using different compositions of PW or of other brine compositions (e.g., desalination brine discharge). $\mathrm{CaCO}_{3}$ yields will be significantly affected by total $\mathrm{Ca}^{2+}$ concentrations, whereas purities will significantly be affected by total $\mathrm{Mg}^{2+}$ and $\mathrm{Fe}^{2+/ 3+}$ concentrations as the results have shown.

\section{Process Design}

The results from these studies indicate that ion exchange processes can be used as an alternative to the addition of stoichiometric bases to induce alkalinity for the precipitation of $\mathrm{CaCO}_{3}$. A process flow diagram for the industrial scale setup is shown in Figure 12. $\mathrm{CO}_{2}$ from flue gas $\left(\mathrm{pCO}_{2}=0.12 \mathrm{~atm}\right)$ is combined with fresh water to provide $\mathrm{H}^{+}$in solution $(\mathrm{pH} 4.4)$ that is used as the inlet solution for the IEX columns. Minor acidic impurities in the flue gas (e.g., sulfur) are not expected to substantially impact the process performance (e.g., $\mathrm{H}^{+}$exchange capacities). The carbonate-rich effluent of the columns $(\mathrm{pH}>$ $10)$ is mixed with the calcium-rich produced water in a precipitation reaction to produce $\mathrm{CaCO}_{3}$. Following separation of the solids, the remaining solution undergoes a nanofiltration step for the removal of the remaining divalent cations in solution that would inhibit regeneration of the IEX columns (e.g., $\mathrm{Ca}^{2+}, \mathrm{Mg}^{2+}$ and $\mathrm{Fe}^{2+/ 3+}$ cations preferably exchanging at the exchanging sites instead of $\mathrm{Na}^{+}$cations). Performance studies of nanofiltration membranes are required to quantify the compositions of these cations following this step as they may decrease IEX performance (e.g., regeneration capacities and cycles). A reverse osmosis step is implemented for the continuous production of fresh water that is used in the first step of the IEX process and for simultaneous concentration of sodium cations in solution used for regeneration of IEX columns. The $\mathrm{pH}$ in both retentate and permeate streams of the reverse-osmosis step would have to be monitored as this can effect regeneration time and $\mathrm{CO}_{2}$ absorption. The retentate is transferred to the IEX columns for regeneration, where a larger $\mathrm{pH}$ would result in a faster regeneration time. The permeate is utilized for the initial carbonation step, where a larger $\mathrm{pH}$ would result in larger $\mathrm{CO}_{2}$ absorption, inducing a change in $\mathrm{V}_{\mathrm{R}}$ where $\mathrm{CaCO}_{3}$ yields are maximized. High calcium carbonate yields (1-ton $\mathrm{CO}_{2}$ /day) can be achieved by utilizing a $\mathrm{CO}_{2}$ mass flow rate $=69.2 \mathrm{~kg} / \mathrm{min}$, a produced water flow rate $=57.8 \mathrm{~L} / \mathrm{min}$ and a total bed volume $=0.05 \mathrm{~m}^{3}$. The cycling and regeneration efficiency of these IEX materials discussed earlier make this a viable alternative process for $\mathrm{CO}_{2}$ mineralization at standard temperature and pressure.

\section{CONCLUSION}

Our initial discoveries show that the ion exchange process can be used to induce alkalinity through the system to a degree where precipitation is favored. The results from these studies indicate that ion exchange processes can be used as an alternative to the addition of stoichiometric inorganic bases (e.g., sodium hydroxide) to induce alkalinity for the consequent precipitation of $\mathrm{CaCO}_{3}$. Batch equilibrium isotherms showed 


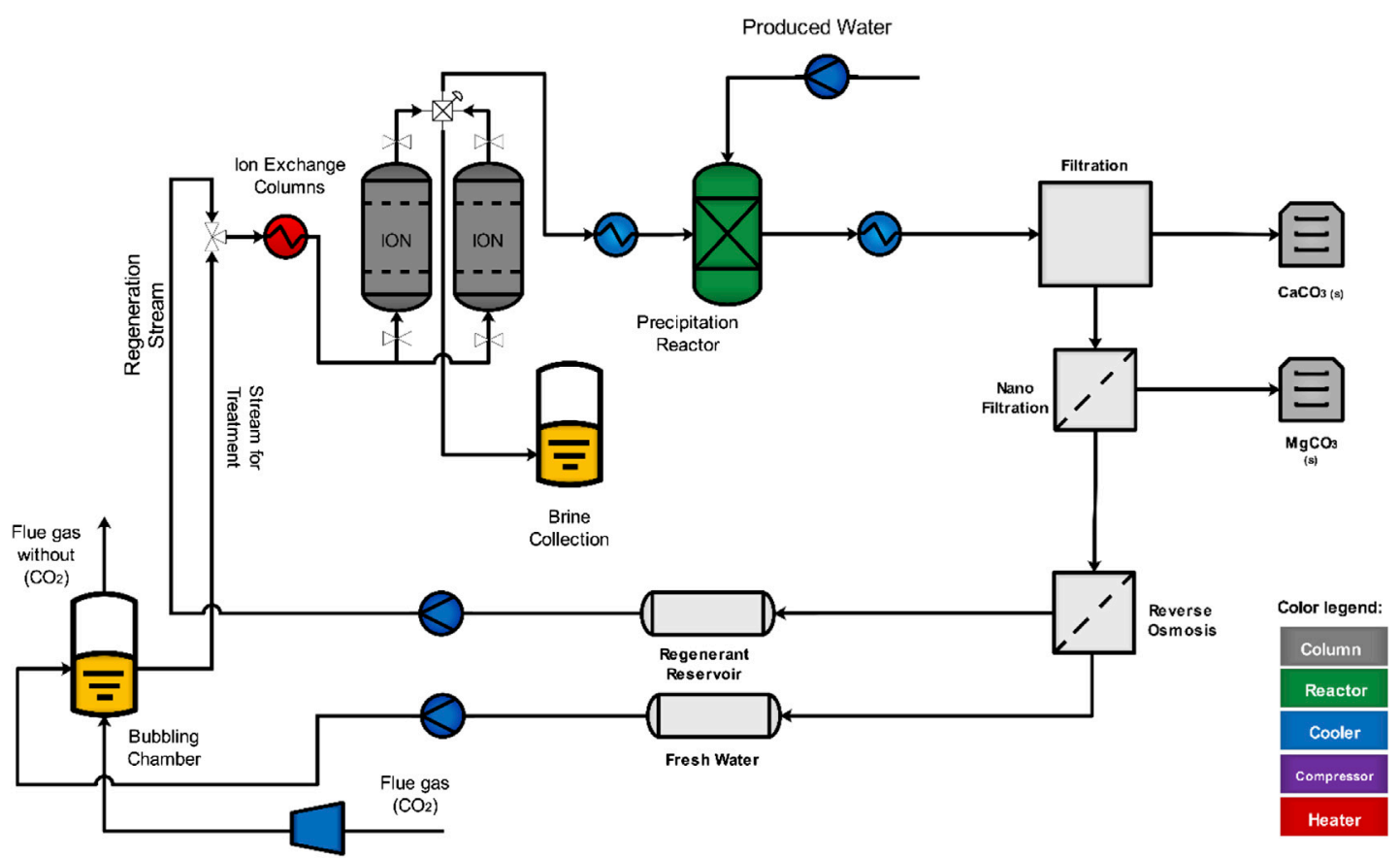

FIGURE 12 | Process flow diagram for industrial scale setup of ion exchange for carbon dioxide mineralization.

larger $\mathrm{H}^{+}$uptake capacities for IEX resins compared to zeolites. For all materials in all conditions, $\mathrm{H}^{+}$uptake increased with a decrease in divalent cation concentrations in solution. Inhibition of $\mathrm{H}^{+}$exchange is likely the result of the larger field strength of divalent cations. Results identified that an inlet stream for the IEX process must be absent of divalent cations in solution. Dynamic IEX experiments showed changes in uptake capacities due to contact time and changes in kinetic bulk parameters due to changes in flow rate implying external diffusion limitations. Capacities for zeolites were smaller than those for IEX resins; $\mathrm{H}^{+}$uptake may be hindered by the porous structure of zeolites. IEX materials were shown to be regenerable using simulated produced water feeds following mineralization.

$\mathrm{CO}_{2}$ mineralization experiments followed thermodynamic predictions with regards to phase formations and concentrations of cations in solutions. Experimental calcite yields were $2.3 \mathrm{~g} / \mathrm{L}$ for cation exchange resins with the formation of goethite (an iron-hydroxide phase, $\mathrm{FeOOH}$ ) as the primary contaminant phase (99\% calcite, $1 \%$ goethite). Yields calculated via simulations were $2.6 \mathrm{~g} / \mathrm{L}$ for the resin, indicating that the experimental process was able to achieve thermodynamic maximum production of calcite. Calcite was the dominant phase for volume ratios $0.2-0.6$, with goethite as the primary contaminant phase. These results indicate high purity of calcite formation and volume ratios required to achieve these purities. The high calcium carbonate yields (1 ton $\mathrm{CO}_{2}$ /day utilizing a produced water flow rate $=57.8 \mathrm{~L} / \mathrm{min}$ and a total bed volume $=0.05 \mathrm{~m}^{3}$ ) obtained for the materials examined and the successful operation at standard temperature and pressure conditions support their potential for industrial implementation.

\section{DATA AVAILABILITY STATEMENT}

The raw data supporting the conclusions of this article will be made available by the authors, without undue reservation.

\section{AUTHOR CONTRIBUTIONS}

SB, AA, and DP conducted experiments and analyzed data. SB, $\mathrm{DP}$, and DS wrote and edited the manuscript. BW and RR edited the manuscript. DS, ELP, GS, and BW conceived the technological concept and directed the research.

\section{FUNDING}

This work was supported by the United States Department of Energy under Award Number DE-FE0031705.

\section{SUPPLEMENTARY MATERIAL}

The Supplementary Material for this article can be found online at: https://www.frontiersin.org/articles/10.3389/fenrg.2020.610392/ full\#supplementary-material. 


\section{REFERENCES}

Allen, D. T. (2016). Emissions from oil and gas operations in the United States and their air quality implications. J. Air Waste Manag. Assoc. 66 (6), 549-575. doi:10.1080/10962247.2016.1171263

Aksu, Z., and Gönen, F. (2004). Biosorption of phenol by immobilized activated sludge in a continuous packed bed: prediction of breakthrough curves. Process Biochem. 39 (5), 599-613. doi:10.1016/S0032-9592(03)00132-8

Armstrong, K., and Styring, P. (2015). Assessing the potential of utilization and storage strategies for post-combustion $\mathrm{CO} 2$ emissions reduction. Front. Energy Res. 3, 1-8. doi:10.3389/fenrg.2015.00008

Avena, M. J., and De Pauli, C. P. (1998). Proton adsorption and electrokinetics of an argentinean montmorillonite. J. Colloid Interface Sci. 202 (1), 195-204. doi:10.1006/jcis.1998.5402

Azdarpour, A., Asadullah, M., Junin, R., Manan, M., Hamidi, H., and Daud, A. R. M. (2014). Carbon dioxide mineral carbonation through $\mathrm{PH}$-swing process: a review. Energy Procedia 61, 2783-2786, doi:10.1016/j.egypro. 2014.12.311

Baker, J. M., Gehrke, C.W., Affsprung, H. E. (1954). An ion-exchange resin-contact time method for the study of inorganic equilibria in milk, J. Dairy Sci. 37 (12), 1409-1415. doi:10.3168/jds.S0022-0302(54)91425-3

Barros, M. A. S. D., Silva, E. A., Arroyo, P. A., Tavares, C. R. G., Schneider, R. M., Suszek, M., et al. (2004). Removal of Cr(III) in the fixed bed column and batch reactors using as adsorbent zeolite NaX. Chem. Eng. Sci. 59 (24), 5959-5966. doi:10.1016/j.ces.2004.07.040

Baseline Survey (2019). Baseline studies overview. Available at: https://netl.doe. gov/node/7512 (Accessed November 4, 2020).

Bhaduri, G. A., Alamiry, M. A. H., and Šiller, L. (2015). Nickel nanoparticles for enhancing carbon capture. J. Nanomater. 2015, 1-13. doi:10.1155/2015/581785

Bhaumik, M., Setshedi, K., Maity, A., and Onyango, M. S. (2013). Chromium(VI) removal from water using fixed bed column of polypyrrole/ $/ \mathrm{Fe}_{3} \mathrm{O}_{4}$ nanocomposite. Separ. Purif. Technol. 110, 11-19. doi:10.1016/j.seppur.2013. 02.037

Blondes, M., Engle, M., Kharaka, Y., Reidy, M., Saraswathula, V., Thordsen, J., et al. (2018). Geological survey national produced waters geochemical database (ver. 2.3, January 2018). Reston, VI: U.S. Geological Survey Data Release.

Blue, C. R., Giuffre, A., Mergelsberg, S., Han, N., De Yoreo, J. J., and Dove, P. M. (2017). Chemical and physical controls on the transformation of amorphous calcium carbonate into crystalline $\mathrm{CaCO}_{3}$ polymorphs. Geochem. Cosmochim. Acta 196, 179-196. doi:10.1016/j.gca.2016.09.004

Bohart, G. S., and Adams, E. Q. (1920). Some aspects OF the behavior OF charcoal with respect to CHLORINE.1. J. Am. Chem. Soc. 42 (3), 523-544. doi:10.1021/ ja01448a018

Borba, C. E., Guirardello, R., Silva, E. A., Veit, M. T., and Tavares, C. R. G. (2006). Removal of nickel(II) ions from aqueous solution by biosorption in a fixed bed column: experimental and theoretical breakthrough curves. Biochem. Eng. J. 30 (2), 184-191. doi:10.1016/j.bej.2006.04.001

Breck, D. (1974). Zeolite molecular sieves: structure, chemistry and use. New York, NY: John Wiley \& Sons Inc.

Bui, M., Gunawan, I., Verheyen, V., Feron, P., Meuleman, E., and Adeloju, S. (2014). Dynamic modelling and optimisation of flexible operation in postcombustion CO2 capture plants-a review. Comput. Chem. Eng. 61, 245-265. doi:10.1016/j.compchemeng.2013.11.015

Cerozi, B. D. S., and Fitzsimmons, K. (2016). The effect of PH on phosphorus availability and speciation in an aquaponics nutrient solution. Bioresour. Technol. 219, 778-781. doi:10.1016/j.biortech.2016.08.079

Chaikittisilp, W., Kim, H.-J., and Jones, C. W. (2011). Mesoporous aluminasupported amines as potential steam-stable Adsorbents for capturing $\mathrm{CO} 2$ from simulated flue gas and ambient air. Energy Fuels 25 (11), 5528-5537. doi:10. $1021 /$ ef201224y

Chang, R., Kim, S., Lee, S., Choi, S., Kim, M., and Park, Y. (2017). Calcium carbonate precipitation for $\mathrm{CO} 2$ storage and utilization: a review of the carbonate crystallization and polymorphism. Front. Energy Res. 5, 2-12. doi:10.3389/fenrg.2017.00017

Chatterjee, S., Mondal, S., and De, S. (2018). Design and scaling up of fixed bed adsorption columns for lead removal by treated laterite. J. Clean. Prod. 177, 760-774. doi:10.1016/j.jclepro.2017.12.249
Choi, S., Drese, J. H., Eisenberger, P. M., and Jones, C. W. (2011a). Application of amine-tethered solid sorbents for direct $\mathrm{CO} 2$ capture from the ambient air. Environ. Sci. Technol. 45 (6), 2420-2427. doi:10.1021/es102797w

Choi, S., Gray, M. L., and Jones, C. W. (2011b). Amine-tethered solid adsorbents coupling high adsorption capacity and regenerability for $\mathrm{CO}_{2}$ capture from ambient air. ChemSusChem 4 (5), 628-635. doi:10.1002/cssc.201000355

Chowdhury, Z. Z., Hamid, S. B. A., and Zain, S. M. (2014). Evaluating design parameters for breakthrough curve analysis and kinetics of fixed bed columns for $\mathrm{Cu}(\mathrm{II})$ cations using lignocellulosic wastes. BioResources 10 (1), 732-749. doi:10.15376/biores.10.1.732-749

Cohen, S. M., Rochelle, G. T., and Webber, M. E. (2012). Optimizing postcombustion $\mathrm{CO} 2$ capture in response to volatile electricity prices. Inter. J. Greenhouse Gas Contr. 8, 180-195. doi:10.1016/j.ijggc.2012.02.011

Cooper, R. S. (1965). Slow particle diffusion in ion exchange columns. Ind. Eng. Chem. Fund. 4 (3), 308-313. doi:10.1021/i160015a012

Dastgheib, S. A., Knutson, C., and Yang, Y. (2014). Produced water from CO2-EOR in the Illinois basin. Energy Procedia 63, 6878-6886. doi:10.1016/j.egypro.2014. 11.722

Di Lorenzo, F., Burgos-Cara, A., Ruiz-Agudo, E., Putnis, C. V., and Prieto, M. (2017). Effect of ferrous iron on the nucleation and growth of $\mathrm{CaCO} 3$ in slightly basic aqueous solutions. CrystEngComm 19 (3), 447-460. doi:10.1039/ C6CE02290A

Dinu, M. V., and Dragan, E. S. (2008). Heavy metals adsorption on some iminodiacetate chelating resins as a function of the adsorption parameters. React. Funct. Polym. 68 (9), 1346-1354. doi:10.1016/j.reactfunctpolym.2008.06. 011

Drage, T. C., Snape, C. E., Stevens, L. A., et al. (2012). Materials challenges for the development of solid sorbents for post- combustion carbon capture. J. Mater. Chem. 22 (7), 2815-2823. doi:10.1039/C2JM12592G

Druckenmiller, M. L., and Maroto-Valer, M. M. (2005). Carbon sequestration using brine of adjusted $\mathrm{PH}$ to form mineral carbonates. Fuel Process. Technol. 86 (14), 1599-1614. doi:10.1016/j.fuproc.2005.01.007

Dutcher, B., Fan, M., and Russell, A. G. (2015). Amine-based CO2 capture technology development from the beginning of 2013-a review. ACS Appl. Mater. Interfaces 7 (4), 2137-2148. doi:10.1021/am507465f

Dyer, A., and Gettins, R. B. (1970). The mobility of cations in synthetic zeolites with the faujasite framework - III: self-diffusion of cations into $\mathrm{X}$ and $\mathrm{Y}$ zeolites from non-aqueous solutions. J. Inorg. Nucl. Chem. 32 (7), 2401-2410. doi:10.1016/0022-1902(70)80523-1

El Hadri, N., Quang, D. V., Goetheer, E. L. V., and Abu Zahra, M. R. M. (2017). Aqueous amine solution characterization for post-combustion $\mathrm{CO} 2$ capture process. Appl. Energy 185, 1433-1449. doi:10.1016/j.apenergy.2016.03.043

El-Kamash, A. M. (2008). Evaluation of zeolite A for the sorptive removal of Cs+ and $\mathrm{Sr} 2+$ ions from aqueous solutions using batch and fixed bed column operations. J. Hazard Mater. 151 (2), 432-445. doi:10.1016/j.jhazmat.2007.06. 009

Federal Highway Administration (2016). Blast furnace slag - material description user guidelines for waste and Byproduct materials in pavement construction FHWA-RD-97-148. Available at: https://www.fhwa.dot.gov/publications/research/ infrastructure/structures/97148/bfs1.cfm\#: :text=It\%20is\%20estimated\%20that \%20approximately,annually\%20in\%20the\%20United\%20States.\&text=Almost \%20all\%20of\%20the\%20blast,of\%20this\%20slag\%20is\%20ACBFS (Accessed August 4, 2020).

Flanigen, E. M., Broach, R. W., and Wilson, S. T. (2010). Zeolites in industrial separation and catalysis. Hoboken, NJ: John Wiley \& Sons, 1-26. doi:10.1002/ 9783527629565.ch1

Florin, N. H., Blamey, J., and Fennell, P. S. (2010). Synthetic CaO-based sorbent for $\mathrm{CO}_{2}$ capture from large-point sources. Energy Fuel. 24 (8), 4598-4604. doi:10. $1021 /$ ef $100447 \mathrm{c}$

Galvez-Martos, J.-L., Elhoweris, A., Morrison, J., and Al-horr, Y. (2018). Conceptual design of a $\mathrm{CO} 2$ capture and utilisation process based on calcium and magnesium rich brines. J. $\mathrm{CO}_{2}$ Utilizat. 27, 161-169. doi:10. 1016/j.jcou.2018.07.011

Golie, W. M., and Upadhyayula, S. (2016). Continuous fixed-bed column study for the removal of nitrate from water using chitosan/alumina composite. J. Water Process Engin. 12, 58-65. doi:10.1016/j.jwpe.2016.06.007

Gouran-Orimi, R., Mirzayi, B., Nematollahzadeh, A., and Tardast, A. (2018). Competitive adsorption of nitrate in fixed-bed column packed with 
bio-inspired polydopamine coated zeolite. J. Environ. Chem. Engin. 6 (2), 2232-2240. doi:10.1016/j.jece.2018.01.049

Guerra, K., Dahm, K., and Dundorf, S. (2011). Oil and gas produced water management and beneficial use in the western United States. Reclamation Managing Water in the West 157, 1-113.

Guo, H., Ren, Y., Sun, X., Xu, Y., Li, X., Zhang, T., et al. (2013). Removal of Pb2+ from aqueous solutions by a high-efficiency resin. Appl. Surf. Sci. 283, 660-667. doi:10.1016/j.apsusc.2013.06.161

Han, R., Zou, W., Li, H., Li, Y., and Shi, J. (2006). Copper(II) and lead(II) removal from aqueous solution in fixed-bed columns by manganese oxide coated zeolite. J. Hazard Mater. 137 (2), 934-942. doi:10.1016/j.jhazmat.2006.03.016

Harland, C. E. (1994). Ion exchange. Cambridge, UK: Royal Society of Chemistry. doi:10.1039/9781847551184

Helgeson, H. C., Kirkham, D. H., and Flowers, G. C. (1981). Theoretical prediction of the thermodynamic behavior of aqueous electrolytes by high pressures and temperatures; IV, calculation of activity coefficients, osmotic coefficients, and apparent molal and standard and relative partial molal properties to 600 degrees C and 5kb. Am. J. Sci. 281 (10), 1249-1516. doi:10.2475/ajs.281.10.1249

Humbert, P. S., and Castro-Gomes, J. (2019). CO2 activated steel slag-based materials: a review. J. Clean. Prod. 208, 448-457. doi:10.1016/j.jclepro.2018. 10.058

Hummel, W., Berner, U., Curti, E., Pearson, F., and Thoenen, T. (2002). Nagra/PSI chemical thermodynamic data base 01/01. doi:10.1524/ract.2002.90.9-11_2002. 805

IEA (2019). Global energy and $\mathrm{CO}_{2}$ status report 2019-analysis. Available at: https://www.iea.org/reports/global-energy-co2-status-report-2019 (Accessed August 12, 2020).

IEA (2020a). Global CO2 emissions in 2019-analysis in 2019. Available at: https:// www.iea.org/articles/global-co2-emissions-in-2019 (Accessed August 12, 2020).

IEA (2020b). Global energy and CO2 emissions in 2020-global energy review 2020-analysis. Available at: https://www.iea.org/reports/global-energy-review2020/global-energy-and-co2-emissions-in-2020 (Accessed August 12, 2020).

Inglezakis, V. J. (2005). The concept of "capacity" in zeolite ion-exchange systems. J. Colloid Interface Sci. 281 (1), 68-79. doi:10.1016/j.jcis.2004.08.082

Jang, J., and Lee, D. S. (2016). Enhanced adsorption of cesium on PVA-alginate encapsulated prussian blue-graphene oxide hydrogel beads in a fixed-bed column system. Bioresour. Technol. 218, 294-300. doi:10.1016/j.biortech. 2016.06.100

Jin, Y., Teng, C., Yu, S., Song, T., Dong, L., Liang, J., et al. (2018). Batch and fixedbed biosorption of $\mathrm{Cd}(\mathrm{II})$ from aqueous solution using immobilized pleurotus ostreatus spent substrate. Chemosphere 191, 799-808. doi:10.1016/j. chemosphere.2017.08.154

Johnson, J. W., Oelkers, E. H., and Helgeson, H. C. (1992). SUPCRT92: a software package for calculating the standard molal thermodynamic properties of minerals, gases, aqueous species, and reactions from 1 to 5000 bar and 0 to $1000^{\circ}$ C. Comput. Geosci. 18 (7), 899-947. doi:10.1016/0098-3004(92)90029-Q

Kar, S., Goeppert, A., and Prakash, G. K. S. (2019). Integrated $\mathrm{CO}_{2}$ capture and conversion to formate and methanol: connecting two threads. Acc. Chem. Res. 52 (10), 2892-2903. doi:10.1021/acs.accounts.9b00324

Kim, S., Shi, H., and Lee, J. Y. (2016). CO2 absorption mechanism in amine solvents and enhancement of $\mathrm{CO} 2$ capture capability in blended amine solvent. Inte. J. Greenhouse Gas Contr. 45, 181-188. doi:10.1016/j.ijggc.2015.12.024

King, D. W., and Farlow, R. (2000). Role of carbonate speciation on the oxidation of $\mathrm{Fe}(\mathrm{II})$ by $\mathrm{H} 2 \mathrm{O} 2$. Mar. Chem. 70 (1), 201-209. doi:10.1016/S0304-4203(00) 00026-8

Kirov, G., and Filizova, L. (2012). Cationic hydration impact on zeolite formation and properties: a review and discussion. Geokhim., Mineral. Petrol 49, 65-82.

Klein, A. R., Baldwin, D. S., Singh, B., and Silvester, E. (2010). Salinity-induced acidification in a wetland sediment through the displacement of clay-bound iron (II). Environ. Chem. 7, 413-421. doi:10.1071/EN10057

Kralj, D., Kontrec, J., Brecević, L., Falini, G., and Nöthig-Laslo, V. (2004). Effect of inorganic anions on the morphology and structure of magnesium calcite. Chem. Eur J. 10 (7), 1647-1656. doi:10.1002/chem.200305313

Kulik, D. A., Wagner, T., Dmytrieva, S. V., Kosakowski, G., Hingerl, F. F., Chudnenko, K. V. et al. (2012). GEM-selektor geochemical modeling package: revised algorithm and GEMS3K numerical kernel for coupled simulation codes. Berlin, Germany: Springer. doi:10.1007/s10596-012-9310-6
Kunin, R., and Vassiliou, B. (1963). Regeneration of carboxylic cation exchange resins with carbon dioxide. Ind. Eng. Chem. Prod. Res. Dev. 2 (1), 1-3. doi:10. 1021/i360005a001

Leaković, S., Mijatović, I., Cerjan-Stefanović, Š., and Hodžić, E. (2000). Nitrogen removal from fertilizer wastewater by ion exchange. Water Res. 34 (1), 185-190. doi:10.1016/S0043-1354(99)00122-0

Liu, S., Gao, H., He, C., and Liang, Z. (2019). Experimental evaluation of highly efficient primary and secondary amines with lower energy by a novel method for post-combustion CO2 capture. Appl. Energy 233-234, 443-452. doi:10. 1016/j.apenergy.2018.10.031

Lothenbach, B., Kulik, D. A., Matschei, T., Balonis, M., Baquerizo, L., Dilnesa, B., et al. (2019). Cemdata18: a chemical thermodynamic database for hydrated portland cements and alkali-activated materials. Cement Concer Res. 115, 472-506. doi:10.1016/j.cemconres.2018.04.018

Malik, D. S., Jain, C. K., and Yadav, A. K. (2018). Heavy metal removal by fixed-bed column - a review. ChemBioEng Rev. 5 (3), 173-179. doi:10.1002/cben. 201700018

Manzolini, G., Sanchez Fernandez, E., Rezvani, S., Macchi, E., Goetheer, E. L. V., and Vlugt, T. J. H. (2015). Economic assessment of novel amine based $\mathrm{CO} 2$ capture technologies integrated in power plants based on European benchmarking task force methodology. Appl. Energy 138, 546-558. doi:10. 1016/j.apenergy.2014.04.066

Maul, G. A., Kim, Y., Amini, A., Zhang, Q., and Boyer, T. H. (2014). Efficiency and life cycle environmental impacts of ion-exchange regeneration using sodium, potassium, chloride, and bicarbonate salts. Chem. Eng. J. 254, 198-209. doi:10. 1016/j.cej.2014.05.086

Mazur, L. P., Pozdniakova, T. A., Mayer, D. A., Boaventura, R. A., and Vilar, V. J. (2016). Design of a fixed-bed ion-exchange process for the treatment of rinse waters generated in the galvanization process using laminaria hyperborea as natural cation exchanger. Water Res. 90, 354-368. doi:10.1016/j.watres.2015.12. 027

Mondal, M. K. (2009). Removal of $\mathrm{Pb}$ (II) ions from aqueous solution using activated tea waste: adsorption on a fixed-bed column. J. Environ. Manag. 90 (11), 3266-3271. doi:10.1016/j.jenvman.2009.05.025

Mores, P. L., Godoy, E., Mussati, S. F., and Scenna, N. J. (2014). A NGCC power plant with a $\mathrm{CO} 2$ post-combustion capture option. Optimal economics for different generation/capture goals. Chem. Eng. Res. Des. 92 (7), 1329-1353. doi:10.1016/j.cherd.2013.11.013

Munthali, M., Elsheikh, M., Johan, E., and Matsue, N. (2014). Proton adsorption selectivity of zeolites in aqueous media: effect of $\mathrm{Si} / \mathrm{Al}$ ratio of zeolites. Molecules 19 (12), 20468-20481. doi:10.3390/molecules 191220468

Nasef, M. (2008). Polymer grafting and crosslinking. Hoboken, NJ: John Wiley \& Sons, 233-272. doi:10.1002/9780470414811.ch10

Nishiyama, R., Munemoto, T., and Fukushi, K. (2013). Formation condition of monohydrocalcite from $\mathrm{CaCl} 2-\mathrm{MgCl} 2-\mathrm{Na}_{2} \mathrm{CO}_{3}$ solutions. Geochem. Cosmochim. Acta 100, 217-231. doi:10.1016/j.gca.2012.09.002

Nyquist, S., and Ruys, J. (2009). CO2 abatement: exploring options for oil and natural gas companies. New York, NY: McKinsey \& Company.

Oh, S.-Y., Yun, S., and Kim, J.-K. (2018). Process integration and design for maximizing energy efficiency of a coal-fired power plant integrated with aminebased CO2 capture process. Appl. Energy 216, 311-322. doi:10.1016/j.apenergy. 2018.02.100

Ostroski, I. C., Borba, C. E., Silva, E. A., Arroyo, P. A., Guirardello, R., and Barros, M. A. S. D. (2011). Mass transfer mechanism of ion exchange in fixed bed columns. J. Chem. Eng. Data 56 (3), 375-382. doi:10.1021/je100568n

Otton, J. K., and Kharaka, Y. K. (2003). Environmental impacts of Petroleum production: initial results from the osage-skiatook petroleum environmental research sites, Osage County, OK: Diane Publishing. doi:10.3133/wri034260

Puerta-Falla, G., Balonis, M., Falzone, G., Bauchy, M., Neithalath, N., and Sant, G. (2017). Monovalent ion exchange kinetics of hydrated calcium-alumino layered double hydroxides. Ind. Eng. Chem. Res. 56 (1), 63-74. doi:10.1021/acs.iecr. $6 \mathrm{~b} 03474$

Rao, A. B., and Rubin, E. S. (2020). A technical, economic, and environmental assessment of amine-based $\mathrm{CO} 2$ capture technology for power plant Greenhouse gas control. Environ. Sci. Technol. 44 (5), 330. doi:10.1021/ es0158861

Roach, R. W., Carr, R. S., Howard, C. L., and Cain, B. W. (1993). AN assessment OF produced water impacts IN the galveston bay system, 38 . 
Robie, R., and Hemingway, B. (1995). Thermodynamic properties of minerals and related substances at $298.15 \mathrm{~K}$ and 1 bar (105 pascals) pressure and at higher temperatures. San Bernardino County, CA: U.S Geological Survey Bulletin. doi:10.3133/b1452

Robin, V., Tertre, E., Beaufort, D., Regnault, O., Sardini, P., and Descostes, M. (2015). Ion exchange reactions of major inorganic cations (H+, Na+, Ca2+, $\mathrm{Mg} 2+$ and $\mathrm{K}+$ ) on beidellite: experimental results and new thermodynamic database. Toward a better prediction of contaminant mobility in natural environments. Appl. Geochem. 59, 74-84. doi:10.1016/j.apgeochem.2015. 03.016

Rodriguez-Blanco, J. D., Shaw, S., Bots, P., Roncal-Herrero, T., and Benning, L. G. (2014). The role of $\mathrm{Mg}$ in the crystallization of monohydrocalcite. Geochem. Cosmochim. Acta 127, 204-220. doi:10.1016/j.gca.2013.11.034

Ruthven, D. M. (1984). Principles of adsorption and adsorption processes. Hoboken, NJ: Wiley. Available at: https://www.wiley.com/en-us/Principles+of+Adsorption+ and+Adsorption+Processes-p-9780471866060 (Accessed August 12, 2020).

Said, A., Mattila, H.-P., Järvinen, M., and Zevenhoven, R. (2013). Production of precipitated calcium carbonate (PCC) from steelmaking slag for fixation of CO2. Appl. Energy 112, 765-771. doi:10.1016/j.apenergy.2012.12.042

Scanlon, B. R., Reedy, R. C., Xu, P., Engle, M., Nicot, J. P., Yoxtheimer, D., et al. (2020). Can we beneficially reuse produced water from oil and gas extraction in the U.S.? Sci. Total Environ. 717, 137085. doi:10.1016/j.scitotenv.2020. 137085

Seggiani, M., Vitolo, S., and D'Antone, S. (2006). Recovery of nickel from orimulsion fly ash by iminodiacetic acid chelating resin. Hydrometallurgy 81 (1), 9-14. doi:10.1016/j.hydromet.2005.09.005

Seifritz, W. (1990). $\mathrm{CO}_{2}$ disposal by means of silicates. Nature 345 (6275), 486. doi:10.1038/345486b0

Sofia Plagakis (2013). ource of Greenhouse gas emissions, EPA data reveals. Washington, DC: Center for Effective Government. Available at: https://www. foreffectivegov.org/oil-and-gas-production-major-source-of-greenhouse-gasemissions-epa-data-reveals (Accessed August 4, 2020).

Teir, S., Eloneva, S., Fogelholm, C.-J., and Zevenhoven, R. (2007). Dissolution of steelmaking slags in acetic acid for precipitated calcium carbonate production. Energy 32 (4), 528-539. doi:10.1016/j.energy.2006.06.023
Thoenen, T., Hummel, W., Berner, U., and Curti, E. (2007). The PSI/nagra chemical thermodynamic database 12/07; villigen PSI. Villigen, Switzerland: Paul Scherrer Institut.

Townsend, R. P. (1991). "Chapter 10 ion exchange in zeolites," in Studies in surface science and catalysis. Introduction to zeolite science and practice. Editors H. van Bekkum, E. M. Flanigen, and J. C. Jansen (Amsterdam, Netherlands: Elsevier), Vol. 58, 359-390. doi:10.1016/S0167-2991(08)63608-3

U.S. Department of Energy (2019). Natural gas flaring and venting: state and federal regulatory Overview. Trends, and impacts.

Víctor-Ortega, M. D., Ochando-Pulido, J. M., and Martínez-Ferez, A. (2017). Impacts of main parameters on the regeneration process efficiency of several ion exchange resins after final purification of olive mill effluent. Separ. Purif. Technol. 173, 1-8. doi:10.1016/j.seppur.2016.08.037

Wachinski, A. M. (2017). Environmental ion exchange: principles and design. 2nd Edn. Boca Raton, London, New York: CRC Press, Taylor \& Francis Group.

Wagner, T., Kulik, D. A., Hingerl, F. F., and Dmytrieva, S. V. (2012). Gem-selektor geochemical modeling package: TSolMod library and data interface for multicomponent phase models. Cancer Mineral. 50 (5), 1173-1195. doi:10. 3749/canmin.50.5.1173

Zhang, W., Liu, H., Sun, Y., Cakstins, J., Sun, C., and Snape, C. E. (2016). Parametric study on the regeneration heat requirement of an amine-based solid adsorbent process for post-combustion carbon capture. Appl. Energy 168, 394-405 doi:10.1016/j.apenergy.2016.01.049

Conflict of Interest: The authors declare that the research was conducted in the absence of any commercial or financial relationships that could be construed as a potential conflict of interest.

Copyright $\odot 2020$ Bustillos, Alturki, Prentice, La Plante, Rogers, Keller, Ragipani, Wang, Sant and Simonetti. This is an open-access article distributed under the terms of the Creative Commons Attribution License (CC BY). The use, distribution or reproduction in other forums is permitted, provided the original author(s) and the copyright owner(s) are credited and that the original publication in this journal is cited, in accordance with accepted academic practice. No use, distribution or reproduction is permitted which does not comply with these terms. 